\title{
La capacidad y la representación de las partes en la jurisdicción contencioso-administrativa*
}

\author{
Eloísa Carbonell Porras
}

Catedrática de Derecho Administrativo

Universidad de Jaén

SUMARIO: I. PERSONALIDAD, CAPACIDAD Y LEGITIMACIÓN: CONSIDERACIONES PREVIAS Y GENERALES: 1. Introducción; 2. La confusión entre legitimación y capacidad: un problema heredado de la anterior Ley de Enjuiciamiento Civil; 3. Capacidad de obrar y legitimación en la legislación de procedimiento administrativo: el rechazo de la doctrina que vincula a los Tribunales con lo apreciado por la Administración. II. CAPACIDAD, LEGITIMAGIÓN Y POSTULACIÓN EN EL PROGESO CONTENCIOSO-ADMINISTRATIVO. III. LA CAPACIDAD PARA SER PARTE Y PARA COMPAREGER EN EL PROGESO CONTENCIOSO-ADMINISTRATIVO: 1 . Los artículos 18 LJCA y 6 LEC, en general; 2. Las personas físicas; 3 . Las personas jurídicas; 4 . La capacidad de los órganos constitucionales y estatutarios; 5 . Los grupos de afectados, las uniones sin personalidad, los patrimonios independientes o autónomos: A. La confusión entre su capacidad y su legitimación en el orden contencioso-administrativo; B. Los patrimonios independientes o autónomos; C. Las «entidades» sin personalidad; D. Los grupos de afectados: a) Los grupos de consumidores y usuarios en la LEC y la distinción entre intereses colectivos y difusos; b) Los grupos de afectados en el proceso contencioso-administrativo y el reconocimiento de su capacidad; c) La capacidad de los grupos políticos parlamentarios. IV. BIBLIOGRAFÍA.

RESUMEN: Constituye el objeto de este estudio el análisis de las condiciones para constituirse en parte en el proceso contencioso-administrativo, es decir, la ca-

* Este trabajo ha sido realizado en el marco del Proyecto I+D+i del Plan Nacional, Las Entidades locales, sus relaciones y competencias. Realidad, efectos y consecuencias de la racionalización y sostenibilidad financiera en clave nacional y europea, (DER2016-74843-C3-1-R), del que soy Investigadora Principal, que se desarrolla en el Grupo de Investigación del Plan Andaluz de Investigación, Desarrollo e Innovación (PAIDI) SEJ-317, «El Derecho Público y la crisis institucional y económica». También deben tenerse en cuenta el Grupo de Excelencia de la Universidad Rey Juan Carlos, «Derecho y política económica» (GEDPE), y el Grupo de Investigación de la Universidad Complutense de Madrid 931089, «Las transformaciones del Estado y la autonomía local: organización institucional, servicios públicos y democracia participativa», en los que colaboro como miembro externo. 
pacidad para ser parte y para comparecer en juicio, que son presupuesto necesario y previo a la legitimación. Para ello, se tiene en cuenta la regulación general que realiza la LEC, que reconoce la capacidad de las personas física y jurídicas, y de otras estructuras no personificadas, y determina a quién le corresponde en cada caso la comparecencia en juicio, y sus consecuencias para el orden contencioso-administrativo.

PALABRAS CLAVE: las partes del proceso contencioso-administrativo, interposición del recurso contencioso-administrativo, capacidad y comparecencia en juicio, las personas y las organizaciones no personificadas, la legitimación.

ABSTRACT: The object of this study is the analysis of the conditions to be part of the administrative process, that is, the capacity to be a party and to appear in court, which are necessary and prior to legitimization. To this end, the general regulation carried out by the LEG is taken into account, which recognizes the capacity of physical and legal persons, and other non-personified structures, and determines to whom corresponds in each case the appearance in court, and its consequences for the contentious-administrative order.

KEY WORDS: the parties in the administrative process, administrative appeal, capacity and appearance in court, legal persons and non-personified organizations, legitimization.

\section{PERSONALIDAD, CAPACIDAD Y LEGITIMACIÓN: CONSIDERA- GIONES PREVIAS Y GENERALES}

\section{Introducción}

El Título II de la Ley 29/1998, de 13 de julio, de la Jurisdicción Contencioso-Administrativa (en adelante, LJCA) está dedicado a «las partes», y, según confiesa su preámbulo, se limita a recoger las modificaciones introducidas por el legislador o la jurisprudencia, a clarificar algunos puntos oscuros y sistematizar los preceptos de la manera más sencilla posible, para «que nadie, persona física o jurídica, privada o pública, que tenga capacidad jurídica suficiente y sea titular de un interés legítimo que tutelar, concepto comprensivo de los derechos subjetivos pero más amplio, pueda verse privado del acceso a la justicia». Esta declaración de principios debe tenerse en todo caso presente pues conecta con el derecho a la tutela judicial efectiva constitucionalmente garantizado. En este título II se tratan la capacidad procesal, la legitimación y la representación y defensa de las partes, que son los nombres de los tres capítulos lo integran. En principio son cuestiones diversas: la capacidad hace referencia a la aptitud para ser parte, la legitimación a la relación con el objeto del proceso de quién puede ser parte, y la representación y defensa en juicio a la intervención de los profesionales del Derecho que son el procurador y el abogado. Sin 
perjuicio de ulteriores precisiones, son nociones generales que también están regulada en la Ley 1/2000, de 7 de enero, de Enjuiciamiento Civil (en adelante, LEG) que le dedica el Capítulo I del Título I, titulado precisamente «De la capacidad para ser parte, la capacidad procesal y la legitimación. Como es sabido, la LEC es de aplicación supletoria en el proceso contencioso-administrativo (Disposición final primera de la LJCA y artículo 4 de la LEG). No obstante, la LJCA fue aprobado año y medio antes, y, por tanto, no tuvo en cuenta las novedades de la LEC que, en este punto, son sumamente relevantes dada la escasa atención que a estos temas generales prestaba la anterior Ley ${ }^{1}$. La Ley de Enjuiciamiento Civil de 1981 carecía de una regulación específica de la legitimación y sus diferencias con la capacidad, lo que ha originado confusión en doctrina y jurisprudencia sobre el alcance y significado de estos conceptos. $\mathrm{Al}$ análisis de estas cuestiones generales y previas se dedica este estudio centrado en el proceso contencioso-administrativo, pero sobre la base de la regulación actual del proceso civil.

\section{La confusión entre legitimación y capacidad: un problema heredado de la anterior Ley de Enjuiciamiento Givil}

En Teoría General del Derecho la capacidad jurídica es la aptitud para ser titular de derechos y de deberes, que se vincula con la personalidad y, en consecuencia, se reconoce a las personas físicas y jurídicas; y la capacidad de obrar es la aptitud para ejercer esos derechos y deberes, que puede ser plena o limitada, necesitando en este último supuesto la intervención de otro sujeto que complete la capacidad como sucede con carácter general con los menores de edad. Esta distinción es equivalente a la que establece el Derecho Procesal entre la capacidad para ser parte y a la capacidad procesal. La capacidad para ser parte o personalidad procesal es la idoneidad para ser titular de los derechos procesales, destinatario de los deberes y sujeto a las cargas y responsabilidades inherentes al proceso civil; y la capacidad procesal es la capacidad para obrar válidamente en el proceso, que se reconoce a quienes no tienen limitado el ejercicio de estos derechos, pues, si lo estuvieren, necesitaran completar su capacidad con la representación o con la asistencia, la autorización, o defensa que en cada caso proceda ${ }^{2}$. La capacidad está relacionada con la cualidad del sujeto o

El Proyecto de Ley de Enjuiciamiento Civil fue presentado por el Gobierno el 30 de octubre y calificado el 10 de noviembre de 1998. Sobre esta tema pueden verse con carácter general las monografías de BUSTILLO BOLADO, R.O., La aplicación de la Ley de Enjuiciamiento Civil en el Contencioso-Administrativo, 2005; y de GALLARDO CASTILLO, M ${ }^{\mathrm{a}} \mathrm{J}$., Los problemas de la aplicación supletoria de la LEC en el proceso contencioso-administrativo, 2006.

2 Sobre esta distinción puede verse, entre otros, DE LA OLIVA SANTOS, A. y otros, Comentarios a la Ley de Enjuiciamiento Civil, 2001, pp. 81 ss; ASENCIO MELLADO, J. Mª . (coor.), La Ley de Enjuiciamiento Civil comentada y con jurisprudencia, 2013, pp. 79 ss; o, ARMENTA DEU, T., Lecciones de Derecho Procesal Civil, 2017, pp. 75 ss. 
entidad, al margen de los litigios específicos, del concreto objeto de un proceso. Por el contrario, la legitimación hace referencia a la concreta relación entre un sujeto y el objeto de un determinado proceso, que es la que le permite ejercer la acción e intervenir en ese proceso. Pero la Ley de Enjuiciamiento Civil de 1881 no regulaba detenidamente estas cuestiones; su Título primero, dedicado a la comparecencia en juicio, se limitaba a indicar que podrían comparecer en juicio quienes se encontraban en el pleno ejercicio de sus derechos civiles, y, de no estarlo, comparecerían los representantes legítimos, o los que deban suplir su incapacidad con arreglo a Derecho; que por las corporaciones, sociedades y demás entidades jurídicas comparecerían las personas que legalmente las representen (art. 2); que la comparecencia se realizaría por medio de Procurador legalmente habilitado (art. 3); y no se refería expresamente a la legitimación lo que provocó que esta expresión se empleará con fines diversos ${ }^{3}$. Como ha señalado Montero Aroca cuando doctrina y jurisprudencia hablaban de legitimatio personae, aludían a la capacidad para ser parte y a la capacidad procesal; de legitimatio ad processum, a los supuestos de la representación legal de personas físicas que no están en pleno ejercicio de sus derechos civiles y de la representación necesaria de las personas jurídicas; y de legitimatio ad causam, a la sucesión procesal ${ }^{4}$. Vigente la nueva LEG esta terminología sólo genera confusión pues existe una regulación general de la capacidad para ser parte en el artículo 6, de la comparecencia en juicio en el artículo 7, y de la legitimación en los artículos 9 a 11 bis, entre otras cuestiones generales ${ }^{5}$. Naturalmente un análisis detenido de estos preceptos excede de los objetivos de este estudio, centrado en la jurisdicción contencioso-administrativa y sus particularidades; pero, para hacerlo, hay que partir de diferenciar tres requisitos de aptitud de las partes en el proceso: primero, la capacidad para ser parte, que se vincula con la personalidad; segundo, la capacidad de actuación procesal, o capacidad para comparecer en juicio o capacidad procesal, que permite realizar eficazmente

\footnotetext{
Véase MONTERO AROCA, J., La legitimación en el proceso civil (intento de aclarar un concepto que resulta más confuso cuando más se escribe sobre él), 1994. Todo esto explica la conocida frase de GÓMEZ-ORBANEJA, E., Derecho procesal civil, I, 1976, p. 135: «el concepto de legitimación es uno de los más debatidos y, al mismo tiempo, más confusos del derecho procesal».

Vid. MONTERO AROCA, J., De la legitimación en el proceso civil, 2007, p. 29 ss. De estas cuestiones en general y en el orden contencioso-administrativo se ha ocupado con detalle GÓMEZ DÍAZ, A.B., La legitimación en el proceso contencioso-administrativo, 2014.

5 No obstante, la jurisprudencia continua refiriéndose a la legitimatio personae, a la legitimatio ad processum, y la legitimatio ad causam, con frecuencia en un sentido distinto del originario. Puede verse, en el orden contencioso-administrativo, SSTS de 3 de marzo de 2014 (recurso de casación 4453/2012); o de 1 octubre de 2011 (recurso de casación 3512/2009), y por el Tribunal Constitucional, STC 27/2016, de 18 de febrero o 124/2009, de 18 de mayo, entre otras muchas. A la falsa erudición de estas sentencias se refiere MONTERO AROCA, J. (2007: 38).
} 
actos procesales; y tercero, la capacidad de postulación, requisito de aptitud técnico-jurídica ${ }^{6}$.

A efectos de este trabajo, se recurre a un concepto amplio de capacidad que hace referencia a la posibilidad en abstracto y con carácter general de ser parte (generalmente como demandante) en cualquier proceso contencioso-administrativo; mientras que la legitimación es la relación que se mantiene con el objeto de un concreto proceso que permite sostener la pretensión en el mismo ${ }^{7}$. La primera se regula en el artículo 18 y la segunda en el artículo 19, ambos de la LJCA. Pero también la legislación sobre procedimiento administrativo diferencia ambos conceptos.

\section{Capacidad de obrar y legitimación en la legislación de procedimiento administrativo: el rechazo de la doctrina que vincula a los Tribunales a lo apreciado por la Administración}

La Ley 39/2015, de 1 de octubre, del Procedimiento Administrativo de las Administraciones Públicas (en adelante, LPAC) también diferencia entre quienes pueden relacionarse en abstracto con la Administración y quienes lo hacen en un procedimiento administrativo concreto. El artículo 3 reconoce la capacidad de obrar ante las Administraciones Públicas a las personas físicas o jurídicas que la ostenten con arreglo a las normas civiles. También tienen capacidad de obrar los menores de edad para el ejercicio y defensa de aquellos de sus derechos e intereses cuya actuación esté permitida por el ordenamiento jurídico sin la asistencia de la persona que ejerza la patria potestad, tutela o curatela, salvo que se trate de menores incapacitados cuando la extensión de la incapacitación afecte al ejercicio y defensa de los derechos o intereses de que se trate ${ }^{8}$. La principal novedad es que la LPAC también reconoce capacidad de obrar «cuando la Ley así lo declare expresamente» a «los grupos de afectados, las uniones y entidades sin personalidad jurídica y los patrimonios independientes o autónomos» ${ }^{9}$. No se han producido cambios relevantes en la noción de interesado en

6 Vid. ORTELls RAMOS, M., Derecho Procesal Civil, 2010, p. 117; y, BANACLOCHE PALAO,J. y CUBILLO LÓPEZ, I. J., Aspectos fundamentales de Derecho procesal civil, 2016, pp. 219-221.

7 Sobre la distinción entre capacidad y legitimación en el orden contencioso-administrativo, GONZÁLEZ PÉREZ, J., Comentarios a la Ley reguladora de la furisdicción Contencioso-administrativa (Ley 29/1998, de 13 de junio), 2011 , en particular, pp. 272 y 282-283.

8 La legislación administrativa siempre ha ampliado la capacidad de obrar respecto de las normas civiles. Lo hacían los artículos 30 de la Ley 30/1992 y 22 de la Ley de Procedimiento Administrativo de 1958. Este último también se refería a la mujer casada que, como es sabido, tuvo limitada su capacidad hasta la Ley 14/1975, de 2 de mayo, sobre reforma de determinados artículos del Código Civil y del Código de Comercio sobre la situación jurídica de la mujer casada y los derechos y deberes de los cónyuges.

$9 \quad$ La LPAC asume así el reconocimiento de la capacidad para relacionarse con la Administración que ya estaba en diversas leyes. Vid. ALARCÓN SOTOMAYOR, L., «El procedimiento administrativo», en Derecho administrativo II. Régimen jurídico básico y control de la Administración, 2018, pp.33-38. 
el procedimiento administrativo, que serán quienes lo promuevan como titulares de derechos o intereses legítimos individuales o colectivos; los que, sin haber iniciado el procedimiento, tengan derechos que puedan resultar afectados por la decisión que en el mismo se adopte; y aquellos cuyos intereses legítimos, individuales o colectivos, puedan resultar afectados por la resolución y se personen en el procedimiento en tanto no haya recaído resolución definitiva (art. 4 LPAC).

Con carácter general, y sin perjuicio de posteriores consideraciones al respecto, ahora interesa poner de manifiesto que la LPAC no está reconociendo directamente la capacidad de obrar ante las Administraciones Públicas a los grupos de afectados, a las uniones y entidades sin personalidad o a los patrimonios independientes, pues tal capacidad requiere que una «Ley así lo declare expresamente» según dispone la letra c) del artículo 3. También el artículo 28.1 de la Ley 40/2015, de 1 de octubre, de Régimen Jurídico del Sector Público (en adelante, LRJSP) establece que podrán ser sancionados por hechos constitutivos de infracción administrativa, además de las personas físicas y jurídicas, «cuando una Ley les reconozca capacidad de obrar, los grupos de afectados, las uniones y entidades sin personalidad jurídica y los patrimonios independientes o autónomos, que resulten responsables de los mismos a título de dolo o culpa». Por tanto, ni la LPAC ni la LRJSP han reconocido directamente la capacidad de obrar al margen de las estructuras personificadas, pero asumen que existen leyes que así lo disponen. Este es el criterio que también se emplea en el artículo 4. 2 LPAC (como el art. 31 Ley 30/1992) en relación con los intereses colectivos, cuya titularidad corresponde a las asociaciones y organizaciones representativas de intereses económicos y sociales «en los términos que la Ley reconozca». La remisión a otras leyes para reconocer la capacidad y la titularidad de intereses colectivos se repite en el artículo 18 LJCA, respecto de la capacidad procesal en el orden contencioso-administrativo, y en los artículos 7. 3 LOPJ y 19. 1. b) LJCA, que se refieren a la legitimación para la defensa de los intereses colectivos por quienes «estén legalmente habilitados para su ejercicio». De esta forma, para relacionarse con las Administraciones Públicas por tener capacidad de obrar o representar intereses colectivos se estaría empleando el mismo criterio que exige el proceso contencioso-administrativo para ser parte o estar legitimado en defensa de los intereses colectivos: que la Ley declare o reconozca la capacidad de obrar o habilite para la defensa de intereses colectivos. No se diferencia, como en mi opinión procede, la participación en los procedimientos administrativos y en el proceso contencioso-administrativo, que responden a fines diferentes. La participación en los procedimientos administrativos debe ser lo más amplia posible, comprendiendo a personas pero también a estructuras no personificadas siempre que afecte a sus situaciones jurídico activas o incluso sin esa afectación en un trámite de información pública; del mismo modo, la habilitación legal para defender intereses colectivos sólo debe exigirse para interponer un recurso 
contencioso-administrativo. En la adopción de las decisiones administrativas debería posibilitarse la más amplia participación y colaboración de cualquier organización no personificada ni habilitada para la defensa de intereses colectivos sin necesidad de expresas previsiones legales, requisitos que sí son exigibles cuando se trata de acudir a la jurisdicción contencioso-administrativa ${ }^{10}$.

Sin embargo, como es sabido, la práctica jurisprudencial que rechaza que la Administración cuestione la legitimación procesal de quién participó en el procedimiento administrativo dificulta esta distinción, al defender que la Administración no puede negar en vía judicial la legitimación ni la capacidad a quienes participaron en el procedimiento administrativo previo ${ }^{11}$. Esta doctrina jurisprudencial estaba plenamente justificada cuando, vigente la LJCA 1956, se exigía un interés directo para interponer recurso contencioso-administrativo pues permitió ampliar significativamente el acceso a la jurisdicción contencioso-administrativo. Pero, superadas todas las limitaciones al respecto, con un amplísimo reconocimiento de la legitimación en el orden contencioso-administrativo, no hay razones que justifiquen la aplicación de los mismos criterios en el procedimiento administrativo y en el proceso contencioso-administrativo. Los Tribunales Contencioso-administrativos deben analizar los presupuestos del recurso contencioso-administrativo con sujeción a las reglas que lo rigen, sin ningún tipo de vinculación con lo que haya podido considerar la Administración que, en consecuencia, podrá alegar en el proceso contencioso-administrativo lo que considere oportuno en aplicación de esas mismas reglas procesales. La propia legislación de procedimiento administrativo admite incluso la intervención en un procedimiento de interesados plurales: cuando una pluralidad de personas tengan unas pretensiones con contenido y fundamento similar podrán formularlas en una única solicitud (art. 66 LPAC) y las actuaciones se entenderán con el representante o el interesado que expresamente hayan señalado y, en su defecto, con el que figure en primer término (art. 7 LPAC). En mi opinión, un «grupo de afectados» son una pluralidad de interesados que no requieren ningún tipo de previsión legal para iniciar un procedimiento administrativo en nombre de todos ellos como se deduce de

10 Respecto de la exigencia de una habilitación legal para defender intereses colectivos en el orden contencioso-administrativo que no debería exigirse para participar en el procedimiento administrativo, CARBONELL PORRAS, E., «Los intereses colectivos en la jurisdicción contencioso-administrativa» en Intereses colectivos y legitimación activa, 2014, pp. 50-51.

11 En apoyo de esta posición jurisprudencial se ha invocado la doctrina del acto propio. Así afirma CIERCO SIEIRA, C., La participación de los interesados en el procedimiento administrativo, 2002, pp. 188-189 que «esta regla encuentra su fundamento en el conocido brocardo venire contra factum propium non valet - con el que se resume la «doctrina de los actos propios»-, el cuál entronca a su vez directamente con los principios de buena fe y confianza legítima hoy proclamados en el art. 3. 1 de la LAP». También GONZÁLEZ PÉREZ, J. (201 1: 273) o MENÉNDEZ GARCÍA, P., «Capacidad procesal y legitimación ante la jurisdicción contencioso-administrativa» en Por el Derecho y la Libertad, 2014, p. 781. 
estos artículos de la LPAC. Otro tema es cómo podrán actuar colectivamente en el proceso contencioso-administrativo al carecer de personalidad jurídica. Por todo esto, coincido con quienes afirman que la jurisprudencia que niega que los órganos jurisdiccionales puedan cuestionar la capacidad procesal o la legitimación de quién fue interesado en el procedimiento administrativo, carece de fundamento técnico-jurídico y es contraria a la plena competencia de los Tribunales para decidir sobre ambas cuestiones sin vinculación alguna con el criterio previamente adoptado por la Administración ${ }^{12}$. También se ha pronunciado en tal sentido el Tribunal Supremo en alguna ocasión ${ }^{13}$. Otra cosa es que los Tribunales, en aplicación de las reglas procesales correspondientes, concluyan aceptando la capacidad o la legitimación como con anterioridad haya hecho la Administración, o con apoyo en el expediente administrativo aportado en el proceso contencioso-administrativo como tendremos ocasión de señalar.

\section{GAPACIDAD, LEGITIMAGIÓN Y POSTULACIÓN EN EL PROGE- SO CONTENGIOSO-ADMINISTRATIVO}

La LJCA parece diferenciar con claridad la capacidad de la legitimación, regulando cada una de ellas en un capítulo diferente de su Título II, que es el que dedica a las partes, prestando mayor atención a la legitimación. Frente a un único precepto, el artículo 18, relativo a la capacidad procesal, se dedican cuatro a la legitimación: el artículo 19, que relaciona los diferentes sujetos legitimados, así como los distintos criterios de legitimación; el artículo 20, que establece las prohibiciones de recurrir; el artículo 21, relativo a la parte demandada; y el artículo 22, sobre la sucesión procesal. Sin duda el artículo 19 es el más relevante y el que históricamente ha suscitado mayores problemas pues determina quienes pueden acceder a la jurisdicción contencioso-administrativa en defensa de sus pretensiones, que también son diferentes según quién sea el sujeto actor. A efectos de este estudio las cuestiones relativas a la legitimación nos interesan en cuanto están relacionadas con quienes pueden ser parte

12 Vid CORDÓN MORENO, F., El proceso contencioso-administrativo, 1999, p. 94; o GIMENO SENDRA, V. y otros, Comentarios a la nueva Ley reguladora de la furisdicción Contencioso-administrativa de 1998, 1999, p. 216.

13 La STS de 17 de noviembre de 2009 señala que: «En cualquier caso, lo que en principio se aprecia es que en los casos de que ese anterior reconocimiento en fase administrativa, haya sido efectuado por la Administración, lo razonable es sostener, que entonces lo que no será posible es que la Administración cambie de postura en fase judicial, y oponga la falta de legitimación. Pero eso no es el caso que ahora se plantea en que según lo antes expuesto al resolver los anteriores motivos, ha sido el Tribunal de la anterior instancia quien en uso de las potestades del art. 33.2 y correlativos de la LJ, ha suscitado el motivo relativo a la falta de legitimación para actuar en la vía judicial. Y ello porque ha apreciado que con los argumentos sobre los que se fundaba el litigio, resultaba posible plantear a las partes la posible concurrencia de la falta de legitimación». También pueden verse las SSTS de 31 de mayo de 2010 y de 22 de mayo de 2008. 
en el proceso y quienes carecen de esta posibilidad con carácter previo y general, es decir, con independencia de que, en su caso, pudieran ostentar una situación jurídico activa legitimante. Por tanto, no se pretende realizar un análisis de la legitimación, entendida como la relación concreta que el recurrente mantiene con el objeto del proceso que le permite defender sus pretensiones, sino reflexionar sobre la capacidad que constituye un requisito previo a la legitimación.

Desde esta perspectiva y sin perjuicio de ulteriores precisiones, el artículo 18 LJCA se refiere a la capacidad procesal de «los grupos de afectados, uniones sin personalidad o patrimonios independientes o autónomos, entidades todas ellas aptas para ser titulares de derechos y obligaciones, al margen de su integración en las estructuras formales de las personas jurídicas»; y la legitimación se reconoce en el artículo 19. 1. b) LJCA a «las corporaciones, asociaciones, sindicatos y grupos y entidades a que se refiere el artículo 18 que resulten afectados o estén legalmente habilitados para la defensa de los derechos e intereses legítimos colectivos»; y, como es sabido, en la letra a), a las «personas físicas o jurídicas que ostenten un derecho o interés legítimo». La idea de la afectación no parece que materialmente tenga un significado diferente de lo que hoy día la jurisprudencia constitucional y ordinaria ha incluido en la noción de interés legítimo: quién «resulta afectado» es titular de un interés legítimo que, por la relación con el objeto del proceso, permite acudir a los Tribunales sin necesidad de más precisiones. Gualquier intento de diferenciar materialmente a los que «resulten afectados» de los que «ostentan un derecho subjetivo o un interés legítimo» creo que está abocado al fracaso. La relación entre el sujeto y el objeto del proceso es similar en las letras a) y b) del artículo 19. 1, salvo en lo relativo a la defensa de los intereses colectivos por quienes estén legalmente habilitados para ello ${ }^{14}$. Esta legitimación, que puede reconocerse a ciertas personas jurídicas como son las corporaciones, asociaciones o sindicatos, es diferente del problema de la capacidad procesal de los grupos y entidades carentes de personalidad como tendremos ocasión de comprobar.

Las partes deben además actuar bajo la representación y defensa de los profesionales del Derecho en los términos previstos en los artículos 23 y 24 LJCA. Corresponde a los Procuradores la representación de las partes y a los Abogados la asistencia jurídica, si bien en los órganos unipersonales los abogados también podrán asumir la representación ${ }^{15}$. La representación y defensa de las Administraciones públicas corresponde generalmente a los Abogados del Estado respecto de la Administración

14 Véase CARBONELL PORRAS, E. (2014: 76 ss.).

15 Sobre la discutible distinción entre la representación en los órganos unipersonales o colegiados, puede verse CANO CAMPOS, T., «Representación y defensa de las partes», en REDA núm. 100, 1998, p. 247 ss. Por otra parte, recuérdese que la Ley 42/2015, de 5 de octubre, ha modificado el artículo 23 LJCA para recuperar la regla que permite a los funcionarios públicos comparecer por si mismos en defensa de 
General del Estado, de sus organismos públicos y de sus sociedades mercantiles previo convenio, así como a los cuerpos equivalentes de las Comunidades Autónomas y de las Corporaciones locales ${ }^{16}$. El artículo 24 LEC dispone que el poder otorgando la representación al procurador habrá de estar autorizado por notario o conferirse apud acta por comparecencia personal ante el Letrado de la Administración de Justicia o por comparecencia electrónica ${ }^{17}$. Como es sabido, el escrito de interposición del recurso contencioso-administrativo se acompaña de los documentos que relaciona el artículo 45 LJCA. Ahora nos interesan los previstos en las letras a), el documento que acredita la representación del compareciente, y d), el documento o documentos relativos al cumplimiento de los requisitos exigidos para entablar acciones las personas jurídicas con arreglo a las normas o estatutos que les sean aplicables. Esa exigencia comprende a todas las personas jurídicas, ampliándose así respecto de lo previsto en el artículo 57. 2. d) de la anterior LJCA, que sólo aludía a las Corporaciones e Instituciones. En principio, los documentos exigidos en las letras a) y d) del artículo 45 son diferentes; el primero se refiere al poder de representación procesal y debe de aportarse en todo caso sea quién sea el sujeto recurrente mientras que el segundo sólo se exige a las personas jurídicas para que efectivamente pueda comprobarse que sostiene la pretensión ${ }^{18}$. No obstante, pueden integrarse ambos tipos de documentos en el poder que acredita la representación procesal según dispone el propio artículo 45. 2. d); en tal caso, el poder otorgado para la comparecencia en el proceso contencioso-administrativo podrá incluir no sólo los datos necesarios para acreditar que quién

sus derechos estatutarios, cuando se refieran a cuestiones de personal que no impliquen la separación de los empleados públicos inamovibles.

16 Así, corresponde a los Letrados de la Administración de la Seguridad Social la representación y defensa de las entidades gestoras, servicios comunes y otros organismos que integran la Administración de la Seguridad Social (art. 551 LOPJ). En relación con la representación y defensa de las distintas Administraciones públicas, con especial referencia a las andaluzas, véase LÓPEZ BENÍTEZ, M., «La jurisdicción contencioso-administrativa», en Derecho administrativo II. Régimen jurídico básico y control de la Administración, 2018. pp. 365-366.

17 En la Administración de Justicia también se ha potenciado el empleo de las nuevas tecnologías desde la Ley 18/2011, de 5 de julio. De acuerdo con el artículo 273. 3 de la LEC, reformado mediante Ley 42/2015, de 5 de octubre, están en todo caso obligados a intervenir a través de medios electrónicos con la Administración de Justicia las personas jurídicas y las entidades sin personalidad jurídica.

18 La jurisprudencia ha puesto de relieve que una cosa es el poder de representación, que sólo acredita que el representante está facultado para actuar válida y eficazmente en nombre y por cuenta del representado; y otra distinta la decisión de litigar, de ejercitar la acción, que habrá de ser tomada por el órgano de la persona jurídica a quien las normas reguladoras de ésta atribuyan tal facultad ya que en otro caso se abre la posibilidad, el riesgo, de iniciación de un litigio no querido, o que jurídicamente no quepa afirmar como querido, por la entidad que figure como recurrente. Pueden verse, entre otras, las SSTS 990/2017 de 5 junio (recurso de casación 2620/2016) o 1894/2016 de 20 julio (recurso de casación 2596/2013. 
recurre es la persona jurídica, sino también los que sean precisos en cada supuesto para salvar las dudas sobre la capacidad del sujeto recurrente ${ }^{19}$.

En todo caso, cualquier duda sobre la capacidad constituye un defecto subsanable. Con esta finalidad, el artículo 45. 3 LJCA dispone que el Letrado de la Administración de Justicia examina de oficio la validez de la comparecencia tan pronto como se haya presentado el escrito de interposición del recurso contencioso-administrativo y, si estima que no se acompaña con los documentos exigidos, los presentados son incompletos o considera que no concurren los requisitos para la validez de la comparecencia, requiere inmediatamente la subsanación, señalando un plazo de diez días para ello. Si el recurrente no realiza la subsanación, el Juez o Tribunal se pronuncia sobre el archivo de las actuaciones. Después de la interposición del recurso habrá que estar a lo previsto en el artículo 138 LJCA, que diferencia el régimen de subsanación de los actos procesales según el defecto se alegue por las partes o se aprecie de oficio, estableciendo un plazo de diez días desde que se notifique el escrito con la alegación en el primer caso o se dicte por el Letrado de la Administración de Justicia la diligencia de ordenación que lo reseñe. La jurisprudencia ha considerado que, cuando el defecto procesal ha sido alegado por la contraparte, no resulta exigible que el Tribunal requiera la subsanación. Esta interpretación ha sido matizada con posterioridad por Tribunal Supremo exigiendo el requerimiento de oficio también si el defecto en la comparecencia fue alegado por la contraparte cuando esta alegación no fue clara, o fue rechazada y la ausencia de requerimiento pueda generar indefensión ${ }^{20}$. Esta es

19 Vid. STS de 16 de febrero de 2015 (recurso de casación 3882/2013). No obstante, la STS de 8 de septiembre de 2011 (recurso de casación 2314/2008) establece que «los juicios de valor del Notario sobre la suficiencia de las facultades de representación, tanto si el fedatario es español como extranjero, al no ser hechos de los que se pueda dar fe, no tienen valor vinculante en el proceso contencioso-administrativo ni para los terceros que no intervinieron en su otorgamiento, pudiendo por ello ser cuestionados y desvirtuados tales juicios de valor».

20 La doctrina inicial, que rechaza el requerimiento de subsanación cuando el defecto ha sido alegado por las partes, se sienta en la STS de 5 de noviembre de 2008 (recurso de casación 4755/2005) que se invoca con posterioridad en numerosas ocasiones. No obstante, con anterioridad la STS de 2 de julio de 2008 (recurso de casación 4029/2004) ya había matizado esa conclusión por exigencias del artículo 24 de la Constitución de modo que, «alegado el defecto por las partes, será exigible el requerimiento de subsanación por el órgano jurisdiccional cuando, sin él, pueda generarse una situación de indefensión lo que ocurre si la alegación no fue clara, o si fue combatida y no se comparten los argumentos opuestos. En tales casos, resulta exigible una advertencia implícita, a través del previo requerimiento, de lo infundado de esos argumentos y de la confianza nacida de ellos de obtener una sentencia que, como demanda aquel contenido normal, se pronuncie sobre el fondo de la cuestión litigiosa». Este planteamiento se repite en otras sentencias como la de 19 de mayo de 2015 (recurso de casación 3743/2013), o de 12 de abril de 2013 (recurso de casación 1543/201 1), entre otras muchas. Por su parte, el Tribunal Constitucional ha estimado los recursos de amparo interpuestos contra las sentencias que no ofrecieron la posibilidad de subsanación. De este tema se ha

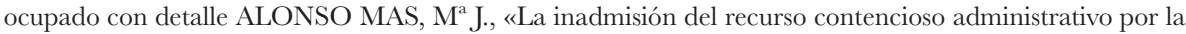
falta de aportación del acuerdo para el ejercicio de acciones: el caso de las sociedades con administrador único», en $R G D A$ núm. 45, 2017, con amplias referencias jurisprudenciales y doctrinales. 
la doctrina a mi juicio correcta teniendo en cuenta que lo que está en juego es el derecho a la tutela judicial efectiva en su vertiente de acceso a la jurisdicción ${ }^{21}$. Por eso, la jurisprudencia ha admitido la subsanación realizada en cualquier fase del proceso ${ }^{22}$.

\section{LA GAPACIDAD PARA SER PARTE Y PARA COMPAREGER EN EL PROGESO GONTENCIOSO-ADMINISTRATIVO}

\section{Los artículos 18 LJGA y 6 LEG, en general}

El articulo 18 LJCA contempla la capacidad procesal en el orden contencioso-administrativo y la reconoce, en el apartado 1, a quienes la ostenten con arreglo a la legislación procesal general. También se afirma que cuentan con capacidad los menores de edad para la defensa de aquellos de sus derechos e intereses legítimos cuya actuación les esté permitida por el ordenamiento jurídico sin necesidad de asistencia de la persona que ejerza la patria potestad, tutela o curatela. Además, el apartado 2 de este artículo 18 dispone que:

«Los grupos de afectados, uniones sin personalidad o patrimonios independientes o autónomos, entidades todas ellas aptas para ser titulares de derechos y obligaciones, al margen de su integración en las estructuras formales de las personas jurídicas, también tendrán capacidad procesal ante el orden jurisdiccional contencioso-administrativo cuando la Ley así lo declare expresamente».

Lo primero que debe notarse es que este precepto se refiere a la capacidad procesal en un sentido amplio, sin diferenciar la capacidad para ser parte y la capacidad para comparecer o de actuación procesal en los términos antes indicados. Además se hace eco de la superación del criterio de la personalidad jurídica en materia procesal, y desvincula la capacidad del concepto de persona con la finalidad de permitir el ac-

Recientemente la STC 12/2017, de 30 de marzo, estima el recurso de amparo interpuesto por un sindicato contra la no admisión de su recurso contencioso-administrativo a pesar de que en el poder notarial constaban, transcritos por el notario, los acuerdos confiriendo la facultad para entablar acciones al Secretario General; y la STC 6/2018, de 22 enero, porque no se tuvo en cuenta la certificación del acta de la junta general de la sociedad, extendida por uno de sus administradores solidarios, que ratificaba la decisión de éstos de interponer el recurso.

21 Así lo señale en CARBONELL PORRAS, E., «Incidentes e invalidez de los actos procesales», en REDA núm. 100, 1999, pp. 904-905.

22 La STS de 14 septiembre de 2015 (recurso de casación 3805/2013), rechaza que «precluido el procedimiento no era permitido a la recurrente presentar el documento acreditativo del acuerdo societario para recurrir»; o la STS de 19 de mayo de 2015 (recurso de casación 3743/ 2013), en relación con la subsanación mediante la aportación de la documentación oportuna con ocasión del trámite de conclusiones. También, entre otras, las SSTS de 20 de enero de 2012 (recurso de casación 6878/2009) o de 2 de julio de 2008 (recurso de casación 4029/2004). 
ceso a los Tribunales aunque no exista personalidad ${ }^{23}$. Pero se trata de un reconocimiento limitado, pues no es directo y expreso sino en función de la existencia de una Ley que así lo declare; es decir, para la LJCA la capacidad de los grupos, las uniones sin personalidad o patrimonios independientes o autónomos en el proceso contencioso-administrativo tendrá que establecerse expresamente en otra Ley, que es el mismo criterio que utiliza la LPAC. Por eso, el precepto tiene particular incidencia en una de las partes del proceso contencioso-administrativo, que son los particulares ${ }^{24}$.

Para concretar la capacidad en el proceso contencioso-administrativo lo primero será comprobar quienes la ostentan con arreglo a la legislación procesal general a la que remite el artículo 18 LJCA. El artículo 6. 1 LEC dispone que podrán ser parte en los procesos ante los Tribunales civiles:

« $1^{\circ}$ Las personas físicas.

$2^{\circ}$ El concebido no nacido, para todos los efectos que le sean favorables.

$3^{\circ}$ Las personas jurídicas.

$4^{\circ}$ Las masas patrimoniales o los patrimonios separados que carezcan transitoriamente de titular o cuyo titular haya sido privado de sus facultades de disposición y administración.

$5^{\circ}$ Las entidades sin personalidad jurídica a las que la ley reconozca capacidad para ser parte.

$6^{\circ}$ El Ministerio Fiscal, respecto de los procesos en que, conforme a la ley, haya de intervenir como parte.

$7^{\circ}$ Los grupos de consumidores o usuarios afectados por un hecho dañoso cuando los individuos que lo compongan estén determinados o sean fácilmente determinables. Para demandar en juicio será necesario que el grupo se constituya con la mayoría de los afectados.

$8^{\circ}$ Las entidades habilitadas conforme a la normativa comunitaria europea para el ejercicio de la acción de cesación en defensa de los intereses colectivos y de los intereses difusos de los consumidores y usuarios».

23 Vid. MENÉNDEZ GARCÍA, P., «Comentario al artículo 18», en Comentarios a la Ley de la furisdicción Contencioso-administrativa de 1998, REDA núm. 100, 1999, p. 213 y, más reciente, «Capacidad procesal y legitimación ante la jurisdicción contencioso-administrativa», en Por el Derecho y la Libertad, 2014, en particular pp. 784-785.

24 Así lo pone de relieve BOTO ÁLVAREZ, A., «Las partes en el proceso contencioso-administrativo», en Estudio de la Ley de la furisdicción Contencioso-Administrativa, 2014, p. 286. 
La nueva regulación de la capacidad para ser parte en la LEC afecta, sin duda, a lo previsto para el proceso contencioso-administrativo ${ }^{25}$. Además el artículo 7 LEC concreta cómo los distintos sujetos que pueden ser parte en el proceso civil comparecen en juicio por sí mismos o por quién en cada caso les representen completando la posible falta de capacidad o los problemas que ésta pueda suscitar. En la LJCA no hay una regulación de la comparecencia ni del apoderamiento o postulación pero, como se verá, los Tribunales Contencioso-administrativos actúan con frecuencia excesivamente apegados a la letra de la LJCA sin tener en cuenta lo previsto para el proceso civil. Seguidamente se intenta analizar conjuntamente la capacidad para ser parte y la comparecencia en juicio integrando la LJCA y la LEC. No obstante, previamente resulta necesaria alguna precisión a propósito del artículo 6.1 LEG.

- Por un lado, el apartado $6^{\circ}$ alude al Ministerio Fiscal, que es un órgano de relevancia constitucional que, desde 2007, cuenta con personalidad jurídica propia, luego su capacidad para ser parte está reconocida en el apartado $3^{\circ}$, que se refiere a las personas jurídicas en general ${ }^{26}$. Este apartado $6^{\circ}$ supone un reconocimiento de que actúa en el proceso en la medida en que la Ley lo haya previsto; legitimación ex lege que se repite en el art. 19. 1. f) LJCA que incluye entre los sujetos legitimados al Ministerio Fiscal «para intervenir en los procesos que determine la Ley».

- Por otro lado, el apartado $8^{\circ}$ se refiere a las «entidades habilitadas conforme a la normativa comunitaria europea para el ejercicio de la acción de cesación en defensa de los intereses colectivos y de los intereses difusos de los consumidores y usuarios». Esta regla no hace referencia a los diferentes sujetos legitimados por el Derecho nacional para ejercer la acción de cesación, sino a aquellas que están legitimadas por el Derecho de la Unión Europea respecto de las cuales sí pueden surgir dudas sobre su capacidad para ser parte en los procesos que se entablen en España ${ }^{27}$.

25 Algunos autores entienden que el artículo 18 LJCA habría dejado de tener sentido con la aprobación de la LEC. Vid. BUSTILLO BOLADO, R.O., (2005: 86); o CALVO ROJAS, E., «Capacidad y legitimación», en Influencia de la Ley de Enjuiciamiento civil en el orden contencioso-administrativo y en el orden social, social, 2000, p. 71. SANTAMARÍA PASTOR, J.A., La ley reguladora de la jurisdicción contencioso-administrativa. Comentario, 2010, p. 215 señala que la regulación de este precepto es «por su carácter parcial, un tanto equívoca y desconcertante».

26 La personificación del Ministerio Fiscal se realiza en el artículo 2. 1 de su Estatuto Orgánico, aprobado por Ley 50/81 de 30 de diciembre, modificado en este punto por la Ley 24/2007, de 9 de octubre.

27 El artículo 54 del Real Decreto Legislativo 1/2007, de 16 de noviembre, por el que se aprueba el texto refundido de la Ley General para la Defensa de los Consumidores y Usuarios y otras leyes complementarias está dedicado a la legitimación para ejercer la acción de cesación y se refiere: al Instituto Nacional del Consumo y los equivalentes de las Comunidades Autónomas, y de las Corporaciones locales; a las asociaciones de consumidores y usuarios; al Ministerio Fiscal, y a las «entidades de otros Estados miembros de la Comunidad Europea constituidas para la protección de los intereses colectivos y de los intereses difusos de los consumidores y usuarios que estén habilitadas mediante su inclusión en la lista publicada a tal fin en el 
Para solucionar cualquier problema al respecto, el artículo 6. 1. $8^{\circ} \mathrm{LEG}$ les reconoce la capacidad para ser parte, y el artículo 11. 4 LEG lo repite, aceptando a tales efectos la lista de entidades habilitadas en los diferentes Estados de la Unión publicada por la Comisión Europea cada seis meses en el Diario Oficial de las Comunidades Europeas $^{28}$. El ordenamiento jurídico español también legitima en otras materias a entidades supranacionales para recurrir ante nuestros Tribunales Contencioso-administrativos, hay que entender que esta legitimación, conlleva el reconocimiento de su capacidad para ser parte en dichos procesos judiciales. Así sucede con las Federaciones deportivas internacionales, los organismos antidopaje de otros Estados, la Agencia Mundial Antidopaje o los Comités Olímpico y Paralímpico Internacionales que están expresamente legitimados para recurrir las resoluciones dictadas por el Tribunal Administrativo del Deporte en materia de dopaje ${ }^{29}$.

\section{Las personas físicas}

Sin duda gozan de capacidad para ser parte en el proceso contencioso-administrativo las personas físicas. La personalidad se adquiere desde el nacimiento con vida «una vez producido el entero desprendimiento del seno materno» y se extingue con la muerte de la persona (arts. 30 y 32 del Código Civil). Carece de personalidad, por tanto, el concebido pero no nacido, aunque el artículo $6.1 .2^{\circ} \mathrm{LEC}$ le reconoce la capacidad para ser parte «para todos los efectos que le sean favorables», criterio que coincide con el previsto en el artículo 29 del Código Civil.

La capacidad para comparecer en juicio se reconoce a las personas físicas que estén en el pleno ejercicio de sus derechos civiles (art. 7.1 LEG), que son los mayores

«Diario Oficial de las Comunidades Europeas». Los Jueces y Tribunales aceptarán dicha lista como prueba de la capacidad de la entidad habilitada para ser parte, sin perjuicio de examinar si la finalidad de la misma y los intereses afectados legitiman el ejercicio de la acción». Con carácter general, puede verse LÓPEZ SÁNCHEZ, J., «La legitimación para el ejercicio de las acciones de cesación en defensa de los intereses colectivos de los consumidores y usuarios», en Intereses colectivos y legitimación activa, 2014, pp. 207-238.

El Instituto Nacional de Consumo fue suprimido por el Real Decreto 19/2014, de 17 de enero, que lo refundió con la Agencia Española de Seguridad Alimentaria y Nutrición para crear la Agencia Española de Consumo, Seguridad Alimentaria y Nutrición que es un organismo autónomo adscrito al Ministerio de Sanidad, Consumo y Bienestar Social.

28 Artículo 4 de la Directiva 2009/22/CE del Parlamento Europeo y del Consejo, de 23 de abril de 2009, relativa a las acciones de cesación en materia de protección de los intereses de los consumidores (versión codificada).

29 Así lo establecen los artículos19.5 LJCA y 40 de la Ley Orgánica 3/2013, de 20 de junio, de protección de la salud del deportista y lucha contra el dopaje en la actividad deportiva. Del recurso especial en materia deportiva he tenido ocasión de ocuparme en CARBONELL PORRAS, E., «La sustitución de los recursos administrativos ordinarios (o la alteración de algún elemento de su régimen general): algunas sugerencias ante el inmovilismo del legislador», en Nuevas perspectivas en la defensa de los ciudadanos frente a las Administraciones Públicas, 2018. 
de edad no incapacitados que no necesitan más requisitos que otorgar el correspondiente poder de postulación y/o defensa jurídica a favor de los profesionales que en cada caso procedan. Quienes no están en pleno ejercicio de sus derechos civiles comparecen en juicio mediante «representación o con la asistencia, la autorización, la habilitación o el defensor exigidos por la Ley» (art. 7.2 LEG). En el caso del nasciturus comparecerá en juicio la persona que legítimamente le representaría si ya hubiera nacido (art. 7.3 LEG). Deberá estarse a las reglas generales del Código Civil y de la LEC teniendo en cuenta los diversos grados de incapacidad, que son correlativos a los diversos medios de integración de la falta de capacidad ${ }^{30}$. Respecto del menor de edad, el orden contencioso-administrativo es más flexible en el reconocimiento de su capacidad para comparecer en juicio por sí mismo. Con esta intención, el artículo 18 LJCA, como su antecesor, reconoce capacidad procesal a los menores para «la defensa de aquellos de sus derechos e intereses legítimos cuya actuación les esté permitida por el ordenamiento jurídico sin necesidad de la persona que ejerza la patria potestad, tutela o curatela». Esta previsión, que está en línea con el artículo 3. b) LPAC, permite entender que, con carácter general, cuando la legislación administrativa permite que el menor se relacione directamente con la Administración, también podrá comparecer ante la jurisdicción contencioso-administrativa por sí mismo $^{31}$.

El principal problema sobre la capacidad procesal de los menores se ha planteado con los inmigrantes y la impugnación ante la jurisdicción contencioso-administrativa de la orden de expulsión, apoyada por la Administración que ejerce la tutela sobre el menor. El Tribunal Constitucional, en su STG 183/2008, de 22 diciembre, que reconoce que no se ha pronunciado específicamente sobre esta cuestión, otorga el amparo pues «la negativa judicial a reconocer capacidad procesal directa al recurrente y, simultáneamente, imposibilitar que pudiera suplir ese defecto de capacidad mediante la designación de un defensor judicial con el argumento de

30 ORTELLS RAMOS, M. (2010: 127-129) diferencia la situación del menor de edad no emancipado, del menor de edad emancipado, del incapacitado por defecto físico o psíquico que le impida gobernarse por sí mismo, del declarado pródigo y del ausente. También CORTÉS DOMÍNGUEZ, V. y MOREnO CATENA, V., Derecho Procesal Civil. Parte general, 2017, pp. 88-89.

31 En la legislación administrativa no todos los menores de edad tienen las mismas limitaciones ni idéntico nivel de tutela institucional como señaló TOLIVAR ALAS, L., «Aspectos jurídico-administrativos de la protección de menores», en RAP núm. 124, 1991, pp. 38 ss. Teniendo en cuenta que la legislación no suelen incorporar reglas relativas a la edad afirma SANTAMARÍA PASTOR, J.A. (2010: 215) que la única interpretación razonable sería «atender a que la norma sustantiva previeses expresamente la titularidad por menores de edad de derechos y obligaciones ante a la Administración (aunque no se pronunciase sobre la posibilidad de actuar por sí mismo tales derechos y obligaciones). Si tal previsión existe, y la norma no exige expresamente la asistencia del padre o tutor, debe presumirse que habilita al menor para actuar por sí ante la Administración; y, por tanto, y en virtud del precepto que comentamos, también ante la jurisdicción contencioso-administrativa» (cursiva del autor). 
que dicha competencia es exclusiva del orden jurisdiccional civil, pero sin permitir tampoco la subsanación del nombramiento realizado por el órgano judicial de instancia, han impedido de manera definitiva a un menor, con capacidad y madurez suficiente, instar el control judicial de una decisión administrativa, como era la de su repatriación, que afectaba de una manera muy directa a su vida y esfera personal, lesionado de esa manera su derecho de acceso a la jurisdicción (art. 24.1 CE), para defender intereses personalísimos» ${ }^{32}$.

En todo caso, deben tenerse en cuenta las relevantes modificaciones que la Ley Orgánica 8/2015, de 22 de julio, introduce en la Ley Orgánica 1/1996, de 15 de enero, de Protección Jurídica del Menor, para ampliar la capacidad de los menores en el ejercicio de sus derechos. Con tal intención, el artículo 2 dispone que «las limitaciones a la capacidad de obrar de los menores se interpretarán de forma restrictiva y, en todo caso, siempre en el interés superior del menor». De este precepto puede deducirse un criterio favorable al reconocimiento de su capacidad para relacionarse con la Administración y también para ser parte en los procesos judiciales, siempre que la edad del menor y el asunto en cuestión lo permitan.

\section{Las personas jurídicas}

En el reconocimiento de la capacidad para ser parte en el proceso a las personas jurídicas debe estarse a las normas reguladoras de las diferentes formas de personificación, que son las que concretan el momento en el que se adquiere la personalidad y cuándo se produce su extinción según disponen con carácter general los artículos 35 y 37 del Código Civil ${ }^{33}$. Respecto de las personas no nacionales rige la

32 La STC 183/2008 estima el recurso de amparo 3319/2007 interpuesto por el menor contra la resolución judicial que apreció su falta de representación y capacidad procesal; y la STC 184/2008 de 22 diciembre, el de la asociación que había intervenido en el proceso bajo la misma representación que el menor, aunque el tribunal contencioso-administrativo rechazó su legitimación activa. En todo caso estas sentencias destacan la necesidad de la audiencia a los menores en todos los procesos judiciales como recuerda la STC 185/2012, de 17 de octubre. Por eso sorprende el Auto del Tribunal Constitucional 96/2010, de 19 de julio, que desestima el recurso de súplica del Ministerio Fiscal contra la providencia de inadmisión del recurso de amparo 5450-2009 al no apreciar especial trascendencia constitucional por no haber oído a un menor sometido a la tutela pública en un procedimiento de repatriación.

33 Por ejemplo, el artículo 5 de la Ley Orgánica 1/2002, de 22 de marzo, reguladora del Derecho de Asociación, establece que las asociaciones adquieren su personalidad jurídica y plena capacidad de obrar con la formalización del acuerdo de constitución, que incluirá los Estatutos, mediante acta fundacional en documento público o privado. Esta regla general se matiza respecto de concretas asociaciones, como los partidos políticos que adquieren personalidad jurídica por la inscripción en el Registro de Partidos Políticos del Ministerio del Interior (art. 3. 4 de la Ley Orgánica 6/2002, de 27 de junio, de Partidos Políticos) y los sindicatos con el depósito de sus estatutos en la oficina correspondiente (art. 4. 1 de la Ley Orgánica 11 / 1985, de 2 de agosto, de Libertad Sindical). La Ley Orgánica 7/1980, de 5 de julio, de Libertad Religiosa, reconoce que las Iglesias, Confesiones y Comunidades religiosas y sus Federaciones gozarán de personalidad jurídica una vez inscritas en el correspondiente Registro público, que se crea, a tal efecto, en el Minis- 
ley personal de acuerdo con el artículo 9 del Código Civil ${ }^{34}$. La comparecencia en juicio de las personas jurídicas corresponde a quienes legalmente las representen según dispone el artículo 7. 4 LEG.

Las Administraciones públicas, como sabemos, gozan de personalidad jurídica y, en consecuencia, con capacidad para ser parte ${ }^{35}$. Los Abogados del Estado y los cuerpos equivalentes de las demás Administraciones públicas asumen su represen-

terio de Justicia (art. 5. 1). Las sociedades de capital adquieren la personalidad jurídica que corresponda con la inscripción en el Registro Mercantil (art. 33 del Real Decreto Legislativo 1/2010, de 2 de julio, por el que se aprueba el texto refundido de la Ley de Sociedades de Capital) y las cooperativas con la inscripción en el Registro de Sociedades Cooperativas (art. 7 de la Ley 27/1999, de 16 de julio, de Cooperativas). Estas leyes también contemplan los supuestos de extinción de la personalidad, regulando además las responsabilidades y régimen jurídico en los periodos transitorios entre la efectiva adquisición y pérdida de la personalidad.

${ }_{34}$ Con apoyo en este precepto, la jurisdicción civil ha reconocido la validez de la postulación de sociedades extranjeras que habían otorgado poder a través de notario radicado en sus respectivos países (SSTS 239/2008, de 24 de marzo, y 429/1994, de 14 de mayo). También se ha considerado capaz desde su consideración como persona jurídica de Derecho Público (y no como una inexistente condición de Estado reconocido en el Derecho internacional) a Gibraltar en la STS 492/2017, de 13 septiembre (sala de lo civil) en recurso extraordinario por infracción procesal y recurso de casación con ocasión de ejercicio del derecho de rectificación frente a una noticia publicada en prensa. En la jurisdicción contencioso-administrativa también se aplica el artículo 45. 2. d) LJCA a las personas jurídicas no nacionales, entre otras, las SSTS de 8 de septiembre de 2011 (recurso de casación 2314/2008) o de 17 mayo 2013 (recurso de casación 152/2012).

35 Así lo establece con carácter general artículo 3. 4 de la LRJSP: «cada una de las Administraciones Públicas del artículo 2 actúa para el cumplimiento de sus fines con personalidad jurídica única». El artículo 2, relativo al ámbito subjetivo de aplicación de la Ley, se refiere a las Administraciones General del Estado, de las Comunidades Autónomas, de las Entidades que integran la Administración Local y del sector público institucional. Este último incluye cualesquiera organismos públicos y entidades de derecho público y de derecho privado vinculados o dependientes de las Administraciones Públicas, así como las Universidades públicas.

Carecen, en consecuencia, de capacidad para ser parte los órganos administrativos y, por eso, no pueden recurrir lo actuado por otros órganos de la misma persona jurídica como ha señalado EMBID IRUJO, A., «Las partes», en Comentarios a la Ley de la furisdicción Contencioso-administrativa, 2001, pp. 142-143. Sería innecesaria la prohibición de recurrir del artículo 20. a) LJCA en lo que a los órganos de una misma Administración se refiere. En relación con la prohibición de que los entes instrumentales recurran contra la Administración de la que dependen, salvo que se les haya dotado de un estatuto que asegure su independencia, no es un problema de capacidad pues la tienen en cuanto personificaciones públicas, sino de imposibilidad legal de sostener una situación jurídico-activa incompatible con la relación de instrumentalidad. Respecto de los miembros de los órganos colegiados, no es una cuestión de capacidad pues evidentemente la tienen las personas fisicas que los integran sino de legitimación. Se trata de impedir que la simple discrepancia en una votación sea título suficiente para impugnar el acto colegial, salvo que una ley lo autorice expresamente como hace la legislación de régimen local respecto del concejal que vota en contra. Lógicamente si el acto colegial afecta a los derechos o intereses legítimos del miembro ningún problema se plantea respecto de su capacidad y su legitimación. Sobre todo ello puede verse, en particular, CARBONELL PORRAS, E., Los órganos colegiados (organización, funcionamiento, procedimiento y régimen jurídico de sus actos), 1999, p. 263 ss, así como «Artículo 63», en Comentarios a la Ley Reguladora de las Bases de Régimen Local, 2007, II, pp. 1465 ss. 
tación procesal de acuerdo con el artículo $551 \mathrm{LOPJ}^{36}$. Generalmente son la parte demandada en el proceso contencioso-administrativo, aunque cada vez son más frecuentes los supuestos en los que ocupan la posición de demandante; además de en el recurso de lesividad y en los conflictos entre las Administraciones públicas territoriales, también es la parte recurrente la Administración contratante que impugna las resoluciones de los Tribunales de resolución de recursos contractuales (art. 19. 4 LJCA); la Agencia Española de Protección de la Salud en el Deporte que recurre las del Tribunal Administrativo del Deporte en materia de dopaje (art. 19. 5 LJCA); o la Comisión Nacional de los Mercados y la Competencia en defensa de la libertad de establecimiento o de circulación (art. 127 bis LJCA). Cuando son las Administraciones públicas las que recurren hay que estar a las respectivas normas que rigen cada organización para precisar a qué órgano administrativo se atribuye la competencia para ejercer la acción judicial ${ }^{37}$. En el caso de las Corporaciones Locales, se requiere el acuerdo del órgano competente para el ejercicio de acciones judiciales según la legislación básica de régimen local: el Pleno en materias de su competencia; el Alcalde/ Presidente en las de la suya, incluidas las delegadas en otros órganos, y, en casos de urgencia, también en materias de competencia plenaria dando cuenta al Pleno en la primera sesión que se celebre para su ratificación; y a la Junta de Gobierno Local de los municipios de gran población respecto de las materias de su competencia ${ }^{38}$. Para el ejercicio de acciones judiciales por la Junta de Andalucía también es necesario un

36 Si se opta por designar Procurador/Abogado, habrá que otorgar el poder de representación procesal como cualquier otro sujeto y aportarlo junto al escrito de interposición del recurso contencioso-administrativo.

37 Por ejemplo, en la Comisión Nacional de los Mercados y la Competencia corresponde al Consejo «acordar, a propuesta del Secretario del Consejo o de otras unidades competentes de la Comisión, la interposición de recursos, la personación en procesos judiciales y procedimientos administrativos y la intervención, como amicus curiae, en los procedimientos a que hace referencia la Ley 1/2000, de 7 de enero, de Enjuiciamiento Civil» — art. 8.2.f) del Real Decreto 657/2013, de 30 de agosto, que aprueba su Estatuto Orgánico. Nada se específica en el Real Decreto 461/2015, de 5 de junio, por el que se aprueba el Estatuto de la Agencia Española de Protección de la Salud en el Deporte.

38 Artículos 21. 1. k) y 22.2.j), respecto de los municipios de régimen común, 33. 2. i) y 34. 1.i), en relación con las Diputaciones Provinciales y 123. 1. m), 124.4.1) y 127.1.j) de la Ley 7/1985, de 2 de abril, reguladora de las Bases del Régimen Local. Un análisis detenido de las competencias sobre el ejercicio de acciones judiciales por los órganos locales puede verse en REBOLLO PUIG, M., GOSÁLVEZ PEQUEÑO, H. y RORÍGUEZ PORTUGUÉS, M.A., «Artículo 21 », en Comentarios a la Ley Reguladora de las Bases de Régimen Local, 2007, I, pp. 506 ss. En el caso de las Corporaciones Locales, la jurisprudencia también exige el informe del Secretario municipal previsto en el artículo 54.3 del Real Decreto Legislativo 781/1986, de 18 de abril, por el que se aprueba el Texto Refundido de las disposiciones legales vigentes en materia de Régimen Local. Véase la STS de 13 marzo de 2015 (recurso de casación 831/2012), que cita otras en el mismo sentido. En todo caso, parece que los Tribunales se muestran más rigurosos en la exigencia de estos documentos respecto de las Corporaciones locales que en relación con las Administraciones estatal y autonómicas. 
acuerdo del Consejo de Gobierno ${ }^{39}$. En relación con la Administración del Estado, los Delegados del Gobierno ostentan la competencia para «velar por el cumplimiento de las competencias atribuidas, constitucionalmente, al Estado y la correcta aplicación de su normativa, promoviendo o interponiendo, según corresponda, conflictos de jurisdicción, conflictos de atribuciones, recursos y demás acciones legalmente procedentes» - art. 23.6 LOFAGE, ahora en el artículo 73. 1. d). $3^{\circ}$ LRJSP - El Tribunal Supremo entiende que se trata de «una competencia de carácter general y transversal..., que como tal no reviste naturaleza exclusiva y excluyente, y por ende no sustituye ni deja sin efecto -sino que se añade- a la que corresponde a los demás órganos de la Administración del Estado para la promoción y defensa de los intereses sectoriales que tienen respectivamente encomendados»; y deduce que «la competencia para acordar el ejercicio de acciones judiciales no se residencia en un órgano concreto de la propia Administración del Estado sino que se trata de una competencia implícita en la sustantiva o material que se actúa en cada caso y en cada proceso (lo que no deja de ser lógico dada la extensión y multiplicidad de cometidos que asume la Administración General del Estado y su consiguientemente compleja estructura organizativa central y periférica)» ${ }^{40}$. En general, los Tribunales suelen ser bastantes más flexibles en la exigencia de la documentación que acredita la voluntad de litigiar de las personas jurídico-públicas (y de las sociedades mercantiles de capital público) de lo que se muestran cuando los recurrentes son personas jurídico-privadas ${ }^{41}$.

Cuando se trata de personas jurídicas privadas, los Tribunales contencioso-administrativos no han sido tan generosos con la documentación que debe aportarse en aplicación del artículo 45. 2. d) LJCA; la jurisprudencia es sumamente casuística, y no resulta sencillo deducir reglas generales sobre qué órgano es competente para el ejercicio de acciones, pues no siempre es fácil conocerlo ${ }^{42}$. Con carácter general, si la

39 Artículo 42 de la Ley 9/2007, de 22 octubre, de Administración de la Junta de Andalucía.

40 Así lo sostiene la STS de 5 marzo de 2013 (recurso de casación 7011/2010), interpretación que confirman las sentencias de 15 de diciembre de 2015 (recurso de casación 3686/2014) o 2026/2016, de 26 de septiembre (recurso de casación 208/2015), entre otras. En consecuencia se entiende cumplido el artículo 45. 2.d) LJCA cuando el Abogado del Estado adjunta al escrito de interposición del recurso contencioso-administrativo la solicitud de interposición del mismo del centro competente por razón de la materia. Además no exigen una autorización específica para interponer el recurso por parte de la Abogacía General del Estado-Dirección del Servicio Jurídico del Estado, siendo suficiente autorizaciones otorgadas con carácter general al amparo del artículo 36.1 del Reglamento del Servicio Jurídico del Estado (Real Decreto $997 / 2003$, de 25 de julio).

${ }^{41}$ También la STS de 19 de julio de 2012 (recurso de casación 2484/2009) considera válidamente acreditada la voluntad de litigar de la Sociedad Estatal de Correos y Telégrafos al aportar un escrito del Director de la Asesoría Jurídica por el que solicita al Servicio Jurídico del Estado que interponga recurso contencioso-administrativo, y el escrito del Subdirector General de los Servicios Contenciosos de la Abogacía del Estado, por el que se da al Abogado del Estado Jefe de Santa Cruz de Tenerife autorización interna para interponer dicho recurso.

${ }^{42}$ Puede verse la crítica de SANTAMARÍA PASTOR, J. A. (2010: 470). 
recurrente es una asociación, las sentencias más recientes han considerado suficiente la decisión del órgano de representación de la asamblea con apoyo en los artículos 11 y 12 de la Ley Orgánica 1/2002, de Asociaciones, rechazando, en consecuencia, que, en ausencia de previsión estatutaria, corresponda a la propia asamblea ${ }^{43}$. Sin embargo, cuando recurre una sociedad mercantil, la jurisprudencia tiende a ser más rigurosa, exigiendo el acuerdo expreso del órgano societario competente para pleitear respecto del asunto en cuestión y los estatutos que así lo confirmen, y, en caso de duda, el de la asamblea ${ }^{44}$. Buena muestra de este rigor es la oscilante jurisprudencia sobre la validez del poder de representación otorgado por el administrador único de las sociedades mercantiles, que es legalmente el único representante de la socie$\operatorname{dad}^{45}$. Los Tribunales contencioso-administrativos deberían tener en cuenta que en las sociedades de capital la representación de la sociedad, «en juicio o fuera de él, corresponde a los administradores en la forma determinada por los estatutos» y que la representación alcanza a «todos los actos comprendidos en el objeto social delimitado en los estatutos», lo que incluye el ejercicio de acciones judiciales ${ }^{46}$.

$43 \quad$ STS de 2 diciembre de 2014 (recurso de casación 4594/2012). En los mismos términos se pronuncia la STS de 10 diciembre de 2010 (recurso de casación 5304/2006), que acepta la ratificación por la Junta Directiva de la decisión de recurrir adoptada por el Presidente de la Asociación después de interponerse el recurso contencioso- administrativo y antes de presentarse la demanda.

44 Así la STS Sentencia de 24 de septiembre de 2015 (recurso de casación 2405/2013) no acepta la certificación del Secretario del Consejo de Administración de la entidad que ratifica «su decisión de continuar las actuaciones legales iniciadas con el recurso de reposición......así como interponer las reclamaciones económico-administrativas o recursos contenciosos que sean pertinentes», que fue adoptado antes de que recayeran las resoluciones expresas impugnadas. También, entre otras muchas, las SSTS 990/2017 de 5 de junio (recurso de casación 2620/2016), 2538/2016 de 30 de noviembre, o 1894/2016, de 20 de julio (recurso de casación núm. 2596/2013).

45 Este supuesto ha sido particularmente controvertido en la jurisprudencia inicialmente dividida que al final se ha inclinado por admitir que corresponde al administrador único de la sociedad, en ausencia de previsión estatutaria que atribuya la facultad para pleitear a la Junta General, considerando que la decisión de interponer el recurso contencioso-administrativo entra dentro de las facultades de representación y administración y, en consecuencia, el poder de representación otorgado por el administrador único resulta suficiente para cumplir el requisito del artículo 45. 2. d) LJCA. No obstante, si se cuestiona tal facultad, será preciso aportar los estatutos societarios para comprobar que el ejercicio de acciones judiciales no es una competencia de otro órgano societario. Puede verse, entre otras, las STS 759/2017, de 4 de mayo (recurso de casación 1578/2016) y 990/2017 de 5 de junio (recurso de casación 2620/2016), que resumen esta jurisprudencia. Un riguroso análisis de esta cuestión lo realiza ALONSO MAS, M J. $^{\mathrm{a}}$ (2017) que defiende que cuando la facultad de decidir el ejercicio de acciones corresponde a un órgano unipersonal de la sociedad mercantil el otorgamiento del poder de postulación que exige el artículo 45. 2. a) LJCA debe considerarse suficiente con sólidos argumentos que comparto.

46 Artículos 233 y 234 del Real Decreto Legislativo 1/2010. De acuerdo con el apartado 2 del artículo 233, la atribución del poder de representación, se rige por las siguientes reglas:

a) En el caso de administrador único, el poder de representación corresponderá necesariamente a éste.

b) En caso de varios administradores solidarios, el poder de representación corresponde a cada administrador, sin perjuicio de las disposiciones estatutarias o de los acuerdos de la junta sobre distribución de facultades, que tendrán un alcance meramente interno. 


\section{La capacidad de los órganos constitucionales y estatutarios}

La jurisdicción contencioso-administrativa también resulta competente para conocer de los recursos que se deduzcan contra ciertos actos y disposiciones del Congreso de los Diputados, del Senado, del Tribunal Constitucional, de las Asambleas Legislativas de las Comunidades Autónomas, del Tribunal de Cuentas y del Defensor del Pueblo y de las instituciones autonómicas análogas, el Consejo General del Poder Judicial y de la Administración electoral según dispone el artículo 1. 3 LJCA. Su capacidad para ser parte en el proceso contencioso-administrativa, con independencia de que gocen o no de personalidad jurídica, se reconoce en el artículo 21. 1. a) LJCA: «se considera parte demandada....cualesquiera de los órganos mencionados en el artículo 1. 3 contra cuya actividad se dirija el recurso» ${ }^{47}$. Los Abogados del Estado asumen la representación y defensa de los órganos constitucionales cuyas normas internas no establezcan un régimen propio, como sucede con las Cortes Generales, el Congreso de los Diputados, el Senado, la Junta Electoral Centra que son representados y defendidos por los Letrados de las Cortes Generales (art. 551 LOPJ).

\section{Los grupos de afectados, las uniones sin personalidad, los patrimonios independientes o autónomos}

A. La confusión entre su capacidad y su legitimación en el orden contenciosoadministrativo

El reconocimiento de capacidad procesal en el orden contencioso-administrativo de los grupos de afectados, las uniones sin personalidad o patrimonios independientes o autónomos, entidades aptas para ser titulares de derechos y obligaciones al margen de su integración en las estructuras formales de las personas jurídicas, requiere que «la Ley así lo declare expresamente» según dispone el artículo 18 LJCA. Por su parte, el artículo 19. 1. b) LJCA se refiere a la legitimación de «las corporacio-

c) En la sociedad de responsabilidad limitada, si hubiera más de dos administradores conjuntos, el poder de representación se ejercerá mancomunadamente al menos por dos de ellos en la forma determinada en los estatutos. Si la sociedad fuera anónima, el poder de representación se ejercerá mancomunadamente.

d) En el caso de consejo de administración, el poder de representación corresponde al propio consejo, que actuará colegiadamente. No obstante, los estatutos podrán atribuir el poder de representación a uno o varios miembros del consejo a título individual o conjunto.

Cuando el consejo, mediante el acuerdo de delegación, nombre una comisión ejecutiva o uno o varios consejeros delegados, se indicará el régimen de su actuación".

Sobre las diferentes modalidades de representación y los actos que comprende puede verse MARTÍNEZ GUTIÉRREZ, A., La representación orgánica y voluntaria en las sociedades de capital: (delimitación y concurrencia), 2005.

47 Señala ORTELLS RAMOS, M. (2010: 119-120) que si los órganos constitucionales y estatutarios tuvieran que ser parte en un proceso civil, su capacidad habría que determinarla con arreglo al artículo 6. $1.5^{\circ} \mathrm{LEC}$, que se refiere a las entidades sin personalidad jurídica a las que la ley reconozca capacidad para ser parte. 
nes, asociaciones, sindicatos y grupos y entidades a que se refiere el artículo 18 que resulten afectados o estén legalmente habilitados para la defensa de los derechos e intereses legítimos colectivos». En términos parecidos, el artículo 7. 3 LOPJ establece que, para la defensa de los intereses legítimos colectivos, «se reconocerá la legitimación de las corporaciones, asociaciones y grupos que resulten afectados o estén legalmente habilitados para su defensa y promoción». De la lectura de estos preceptos, la doctrina ha relacionado los grupos de afectados y entes carentes de personalidad con la defensa de intereses legítimos colectivos y la consiguiente habilitación legal para su tutela ante los Tribunales. Sostiene Embid Irujo que, «tanto desde el plano de la capacidad como del de la legitimación, se incorporan así al cuerpo de la LJCA de 1998 los intereses difusos presentes en sectores de la colectividad no necesariamente organizados de modo perfecto y que ya tuvieron una cierta acogida en el artículo 7. 3 LOPJ con referencia a los "grupos" y el mandato a los Juzgados y Tribunales de la tutela de sus derecho e intereses legítimos» ${ }^{48}$; para Cordón Moreno, el artículo 19. 1. b) LJCA contempla la legitimación de los grupos de afectados y la tutela de los intereses colectivos, es decir, aquellos que pertenecen a la colectividad para, en coherencia con la interpretación amplia del interés legítimo, posibilitar el acceso a la jurisdicción contencioso-administrativa, de los intereses cuya titularidad pertenece a un grupo indeterminado de personas ${ }^{49}$; por su parte, afirma Ruiz Risueño que «la capacidad procesal - y posterior legitimación — de los mencionados grupos carentes de estructuras propias de las personas jurídicas está supeditado a lo que la ley determine, y, en especial, a una de estas dos exigencias: ha de tratarse de grupos afectados por los intereses colectivos de que se trate, o han de estar legalmente habilitados para su defensa y promoción» ${ }^{50}$.

Pero, a mi juicio, hay que diferenciar la habilitación legal para defender intereses colectivos del acceso a la jurisdicción de los grupos de afectados y estructuras no personificadas pues, en el primer caso, sí se trata de un problema de legitimación mientras que en el segundo lo es de capacidad. Una cuestión es que el ordenamiento jurídico tenga que articular mecanismos para que, quienes carecen de personalidad procesal, puedan comparecer como parte en un proceso judicial; y otra diferente es que esa estructura no personificada esté legitimada porque mantiene una relación con el objeto procesal lo suficientemente intensa como para defenderse en los

\footnotetext{
EMBID IRUJO, A. (2001: 149).

CORDÓN MORENO, F. (1999: 105).

RUIZ RISUEÑO, F. El proceso contencioso-administrativo, 1998, p. 178. En términos parecidos, GIMENO SENDRA y otros (1999: 196-197). La misma idea en relación con los grupos de consumidores afectados y la tutela de intereses difusos, en GONZÁLEZ RIVAS, J. J. y ARANGUREN PÉREZ, I., Comentarios a la Ley reguladora de la furisdicción Contencioso-administrativa 29/1998, de 13 de junio, 2006, p. 230; o en ÁLVAREZ- CIENFUEGOS SUÁREZ, J. Ma y GONZÁLEZ RIVAS, J. J., Análisis teórico y jurisprudencial de la Ley de la furisdicción Contencioso-administrativa, 1998, p. 88.
} 
Tribunales. Naturalmente si no se mantiene esa relación se carece de legitimación y no se podrá recurrir aunque se tenga capacidad, salvo que se reconozca la acción pública o una habilitación legal para defender intereses colectivos. La confusión entre legitimación y capacidad se explicaría por la remisión a las leyes que realizan los preceptos de referencia: por un lado, para reconocer la capacidad de las estructuras no personificadas en los artículos 18 LJCA y $6.1 .5^{\circ}$ LEC, que exigen que «la Ley así lo declare expresamente»; y, por otro lado, también la legitimación para la defensa de los intereses colectivos se reconoce a las organizaciones que están legalmente habilitadas para su defensa y promoción según disponen los artículos 7. 3 LOPJ y 19. 1. b) LJCA. Pero esta remisión a la Ley tiene diferente alcance y sentido. En el primer caso, se trata de completar la falta de capacidad para ser parte derivada de la no personificación y, resuelto este problema, podrá interponerse el recurso contencioso-administrativo si invocan un derecho subjetivo o interés legítimo que defender ante los Tribunales ${ }^{51}$. En el segundo supuesto, no hay problema alguno de capacidad procesal que, sin duda, ostentan corporaciones, sindicatos o asociaciones, sino de legitimación para la defensa del interés colectivo que requiere la habilitación o el reconocimiento legal, pues se trata de un interés diferente del interés legítimo de la persona jurídica y de los intereses individuales de los miembros de la corporación, del sindicato o de la asociación, ambos reconocidos en la letra a) del artículo 19. 1 LJCA $^{52}$.

Por lo anterior, respecto de los grupos y entes sin personalidad el problema es cómo articular su comparecencia en juicio pues su legitimación deriva de ostentar una situación jurídico-activa similar a las de las personas físicas y jurídicas. Esa es la intención del artículo 18 LJCA al referirse a los grupos de afectados, uniones sin personalidad o patrimonios independientes o autónomos, «entidades todas ellas aptas para ser titulares de derechos y obligaciones al margen de su integración en las estructuras formales de las personas jurídicas». Se trata, por tanto, de concretar cómo actuarán en el proceso contencioso-administrativo quienes carecen de personalidad respecto de los asuntos que afecten a sus situaciones jurídico activas. A nivel de conceptos, la capacidad es previa a la legitimación: ni las personas, físicas o jurídicas, ni las estructuras carentes de personalidad podrán interponer el recurso contencioso-administrativo si no ostentan el derecho subjetivo o interés legítimo que les legitima, sin perjuicio de la acción pública o una y de la habilitación legal para

51 Ha señalado SANTAMARÍA PASTOR, J. A. (2010: 218) que «no puede discutirse seriamente que estas organizaciones no personificadas debieran tener la condición de parte, pero no, desde luego, que pudieran actuar por sí y comparecer en los procesos, puesto que, al hallarse integradas por una pluralidad de personas su actuación procesal requiere inexorablemente de algún mecanismo de representación; igual que las personas jurídicas. Y como la ley no puede alterar la naturaleza de las cosas parece obligado concluir a lo que este párrafo alude al decir que "tendrán capacidad procesal” es a que podrán tener la condición de parte meramente»

52 Vid. CARBONELL PORRAS, E. (2014: 74 ss). 
defender intereses colectivos. El reconocimiento a esas «entidades» no personificadas del artículo 18 LJCA pretendería impedir que sus situaciones jurídico activas no puedan tutelarse ante los Tribunales por la falta de personalidad, y esta cuestión es la que seguidamente se intenta analizar sobre la base de lo que establece la LEC con carácter general y sin perjuicio de las matizaciones que el proceso contencioso-administrativo pueda requerir.

B. Los patrimonios independientes o autónomos

El artículo 6.1.4 $4^{\mathrm{a}} \mathrm{LEC}$ reconoce capacidad para ser parte a las masas patrimoniales o patrimonios separados que «carezcan transitoriamente de titular o cuyo titular haya sido privado de sus facultades de disposición y administración» y el artículo 7. 5 LEC dispone que su comparecencia en juicio se realizará «por medio de quienes, conforme a la Ley las administren». De esta forma, la propia LEG está reconociendo la capacidad para ser parte con carácter general, sin que resulte exigible otra Ley que así lo establezca como se deduciría del artículo 18 LJCA. Habrá que estar a la Ley para determinar a quién le corresponde la administración del patrimonio. En relación con los bienes de la herencia hasta su aceptación por los herederos, corresponde al administrador de los bienes representar a la herencia en todos los pleitos que se promuevan o que estuvieren principiados al fallecer el causante, así como ejercitar en dicha representación las acciones que pudieran corresponder al difunto, hasta que se haga la declaración de herederos (art. 798 LEG). Respecto de la masa del concurso, resulta de aplicación la Ley 22/2003, de 9 de julio, Concursal, a la que expresamente remite el artículo 7. 8 LEG, añadido por la propia Ley 22/2003. Su artículo 50.2 establece que «los jueces o tribunales de los órdenes contencioso-administrativo, social o penal ante los que se ejerciten, con posterioridad a la declaración del concurso, acciones que pudieran tener trascendencia para el patrimonio del deudor emplazarán a la administración concursal y la tendrán como parte en defensa de la masa, si se personase».

\section{Las «entidades» sin personalidad}

Con carácter general, el artículo 6.1. 5 LEG dispone que podrán ser parte en el proceso civil las «entidades sin personalidad jurídica a las que la Ley reconozca capacidad para ser parte»;y el artículo 7. 7 LEC, que comparecerán en juicio por medio de las «personas que, de hecho o en virtud de pactos de la entidad, actúen en su nombre frente a terceros». El criterio que emplea la LEG no es exactamente coincidente con el del artículo 18 LJCA, que les reconoce capacidad procesal «cuando la Ley así lo declare expresamente». En principio, la LEG es más flexible y, en su aplicación, ya no resulta exigible un reconocimiento expreso de la capacidad para intervenir en el proceso. Esta precisión resulta especialmente relevante en el proceso contencioso-administrativo pues será suficiente que la capacidad se deduzca de la 
regulación legal, aunque no exista una declaración expresa. Además, el legislador se refiere a «entidades sin personalidad», expresión contradictoria pues las Entidades (como las locales o las de Derecho Público) cuentan con personalidad. Prescindiendo de este dato, parece claro que se trataría de incluir cualquier tipo de estructura más o menos organizada carente de personalidad, sea cual sea la razón de esa ausencia de personalidad, como las que están en proceso de adquisición de la personalidad, la tuvieron pero la han perdido, o los grupos y uniones de personas que hayan podido organizarse para cualquier finalidad sin crear una persona jurídica.

La remisión a la Ley que efectúa el artículo 6.1.5 LEG lo es únicamente para ser la parte demandante, pues la propia LEG les reconoce directamente, sin que sea precisa otra Ley, su capacidad para ser parte demandada. Con esta intención, el artículo 6. 2 LEG dispone que «sin perjuicio de la responsabilidad que, conforme a la ley, pueda corresponder a los gestores o a los partícipes, podrán ser demandadas, en todo caso, las entidades que, no habiendo cumplido los requisitos legalmente establecidos para constituirse en personas jurídicas, estén formadas por una pluralidad de elementos personales y patrimoniales puestos al servicio de un fin determinado». En línea con este precepto, el artículo 21. 1. b) LJCA considera parte demandada en el proceso contencioso-administrativo a las «personas o entidades cuyos derechos o intereses legítimos pudieran quedar afectados por la estimación de las pretensiones del demandante». En consecuencia, podrán ser demandadas las personas, físicas o jurídicas, así como cualquier estructura sin personalidad.

La comparecencia en juicio de estas organizaciones no personificadas se sujeta a un régimen diferente según se trate de aquellas a las que la Ley ha reconocido capacidad para ser parte (art. 6.1.5 LEG) o de las que, careciendo de este reconocimiento, pueden ser demandadas en el proceso civil de acuerdo con el artículo 6. 2 LEC. La comparecencia en juicio de las primeras se realiza «por medio de las personas a quienes la Ley, en cada caso, atribuya la representación en juicio» (art. 7. 6 LEG). Por las segundas, comparecerán en juicio «las personas que, de hecho o en virtud de pactos de la entidad actúen en su nombre frente a terceros» (art. 7. 7. LEG). Esta última regla también se aplica a los grupos de consumidores y usuarios afectados por un hecho dañoso como tendremos ocasión de analizar.

En la medida en que una Ley reconoce la capacidad jurídica y de obrar de una estructura no personificada, y concreta quién asume su representación, corresponderá a dicho representante la comparecencia en juicio. Son conocidos algunos ejemplos: 
- La Ley 49/1960 de 21 de julio, de la propiedad horizontal, precisa que el presidente de la comunidad de propietarios ostenta legalmente la representación, en juicio y fuera de él, en todos los asuntos que la afecten (art. 13. 3) $)^{53}$.

- La Ley 55/1980, de 11 de noviembre, de montes vecinales en mano común, aplicable a los que pertenecen a agrupaciones vecinales en su calidad de grupos sociales, reconoce a la comunidad propietaria, «plena capacidad jurídica para el cumplimiento de sus fines, incluido el ejercicio, tanto en vía judicial como administrativa, de cuantas acciones sean precisas para la defensa de sus específicos intereses» (art. 5); y «tanto antes como después de la aprobación de los Estatutos, cualquiera de los partícipes podrá comparecer en juicio en asuntos que afecten a los derechos de la comunidad, ya para ejercitarlos, ya para defenderlos, en cuyo caso las resoluciones que se dicten a su favor aprovecharán a la comunidad, sin que perjudiquen a ésta las contrarias» $(\text { art. 6) })^{54}$.

- La Ley 38/2003, de 17 de noviembre, general de subvenciones, admite que, cuando lo prevean expresamente las bases reguladora, sean beneficiarios de la subvención las «agrupaciones de personas físicas o jurídicas, las comunidades de bienes o cualquier otro tipo de unidad económica o patrimonio separado» carentes de personalidad, que nombraran un «representante o apoderado único de la agrupación» con poderes bastantes para cumplir las obligaciones de la agrupación beneficiaria.

- El Real Decreto Legislativo 5/2015, de 30 de octubre, que aprueba el texto refundido de la Ley del Estatuto Básico del Empleado Público, dispone que «las Juntas de Personal, colegiadamente, por decisión mayoritaria de sus miembros y, en su caso, los Delegados de Personal, mancomunadamente, estarán legitimados para iniciar, como interesados, los correspondientes procedimientos administrativos y ejercitar las acciones en vía administrativa o judicial en todo lo relativo al ámbito de sus funciones» ${ }^{55}$.

53 La jurisprudencia deduce que a las comunidades de propietarios no les es exigible la acreditación documental a que se refiere el artículo 45. 2. d) LJCA. Es suficiente por tanto que el poder notarial indique esa condición. Puede verse, entre otras, la STS 13/2017, de 16 de diciembre (recurso de casación. 2169/2015), y sin perjuicio de aportar el acuerdo de la comunidad como en la STS 1876/2016, de 20 de julio (recurso de casación 3078/2015). Por otra parte, la jurisdicción civil ha declarado que, con independencia de la representación legal del presidente de la comunidad, cualquiera de los comuneros puede comparecer en juicio y ejercitar acciones que competan a la comunidad, siempre que actúe en beneficio de la misma. Por todas, la STS 594/2014 de 30 de octubre (sala de lo civil, recurso de casación 2931/2012) con cita de otras muchas.

54 La STS de 15 junio de 2015 (recurso de casación 2812/2013) considera válida la comparecencia del presidente de la junta directiva que ostentaba la competencia para ejercer acciones por delegación de la asamblea general.

55 Se trata de un reconocimiento limitado al ejercicio de sus funciones, y no de una capacidad para ser parte con carácter general en cualquier proceso como han señalado las SSTS de 2 de febrero de 2006 
- La Ley 9/2017, de 8 de noviembre, de Contratos del Sector Público, por la que se transponen al ordenamiento jurídico español las Directivas del Parlamento Europeo y del Consejo 2014/23/UE y 2014/24/UE, de 26 de febrero de 2014, respecto de las uniones temporales de empresarios que concurran en procedimientos de contratación, que quedan obligados solidariamente, y «deberán nombrar un representante o apoderado único de la unión con poderes bastantes para ejercitar los derechos y cumplir las obligaciones que del contrato se deriven hasta la extinción del mismo» (art. 69. 3).

Cuando la Ley ha reconocido la capacidad para ser titular de derechos y deberes de una estructura no personificada, indicando además quién asume su representación, no deberían surgir problemas en aceptar su comparecencia en el proceso contencioso-administrativo en defensa de derechos subjetivos e intereses legítimos de la estructura. A la misma conclusión debe llegarse cuando la legislación administrativa reconoce que esas organizaciones no personificadas son destinatarias de las potestades de la Administración, aunque no concrete quién asume la representación. Pionera al respecto ha sido la legislación tributaria: además de las personas físicas y jurídicas, son obligados tributarios «en las leyes en que así se establezca, las herencias yacentes, comunidades de bienes y demás entidades que, carentes de personalidad jurídica, constituyan una unidad económica o un patrimonio separado susceptibles de imposición $»^{56}$. Particular interés tiene en este plano el artículo 28 LRJSP, pues establece que podrán ser sancionadas por hechos constitutivos de infracción administrativa «cuando una Ley les reconozca capacidad de obrar, los grupos de afectados, las uniones y entidades sin personalidad jurídica y los patrimonios independientes o autónomos, que resulten responsables de los mismos a título de dolo o culpa». Me parece evidente que, en estos supuestos y al margen de otras objeciones que la responsabilidad sancionadora de las entidades sin personalidad pueda suscitar, tendrán capacidad para ser parte en el proceso contencioso-administrativo ${ }^{57}$. En tales casos, los Tribunales contencioso-administrativos deberán aceptar la comparecencia en juicio de aquel sujeto que haya actuado en el procedimiento sancionador en repre-

(Recurso de casación 2929/2000) y de 1 octubre de 2009 (recurso de casación 3512/2009).

56 Así lo reconocía el artículo 33 de la Ley 230/1963, de 28 de diciembre, General Tributaria, y lo hace el vigente artículo 35 de la Ley 58/2003, de 17 de diciembre. También el artículo 15 del Texto Refundido de la Ley General de la Seguridad Social (Real Decreto Legislativo 1/1994, de 20 de junio), reconoce la responsabilidad en el cumplimiento de la obligación de cotizar y del pago de los demás recursos de la Seguridad Social, de las entidades sin personalidad a las que las normas reguladoras de cada régimen y recurso impongan directamente la obligación de su ingreso.

57 De estas objeciones se ha ocupado REBOLLO PUIG, M., «Responsabilidad sancionadora de personas jurídicas, entes sin personalidad y administradores», en Los retos del Estado y la Administración en el Siglo XXI, 2017, p.1061-1066; y en Ius et Veritas núm. 53, 2016, pp. 233-237, que relaciona diversas leyes que admitían la posibilidad de sancionar a entes no personificados antes de la aprobación de la LRJSP. 
sentación de esa organización no personificada. Podrá pensarse que esta afirmación entra en contradicción con el rechazo a la doctrina que vincula a los Tribunales con lo apreciado por la Administración en el procedimiento administrativo previo al proceso contencioso-administrativo antes defendida, si bien, a mi juicio, son dos temas diferentes. Lo que resulta criticable es que los Tribunales rechacen analizar si un sujeto es capaz y está legitimado aplicando las reglas que procedan con el argumento de que la Administración así lo considero en el procedimiento previo; el procedimiento administrativo y el proceso contencioso-administrativo responden a distintos fines y los criterios que rigen la participación en el primero no coinciden necesariamente con los del segundo. Por eso, los Tribunales no están vinculados por lo que haya apreciado la Administración; y la Administración podrá argumentar en vía contencioso-administrativa que un sujeto carece de capacidad o de legitimación en el orden contencioso-administrativo aunque aceptara su participación en el procedimiento administrativo previo. Otra cuestión es que cuando el legislador convierte a las organizaciones no personificadas en destinatarias de sus potestades esté implícitamente reconociéndoles capacidad en el procedimiento administrativo y obviamente podrán impugnar la actividad de la Administración que afecta a sus situaciones jurídico-activas. Los Tribunales deberán aceptar su capacidad para ser parte y su comparecencia en juicio realizando una interpretación integradora y conforme con la tutela judicial efectiva en su vertiente de acceso a la jurisdicción de lo previsto en la LJCA y en la LEC. Y en esa interpretación integradora los datos que obren en el expediente administrativo pueden constituir un elemento relevante para apreciar la validez de la comparecencia.

D. Los grupos de afectados

a) Los grupos de consumidores y usuarios en la LEC y la distinción entre intereses colectivos y difusos

En línea con el reconocimiento en el artículo 51 de la Constitución de la protección de los legítimos intereses económicos de los consumidores y usuarios, la LEC los reconoce como intereses colectivos que, según su preámbulo, son «llevados al proceso, no ya por quien se haya visto lesionado directamente y para su individual protección, o por grupos de afectados, sino por personas jurídicas constituidas y legalmente habilitadas para la defensa de aquellos intereses» ${ }^{58}$. El artículo 6. 1. $7^{\circ}$ LEC se refiere a la capacidad para ser parte de los grupos de consumidores o usuarios afectados por un hecho dañoso «cuando los individuos que lo compongan estén determinados

58 Sobre los intereses económicos y sociales de los consumidores, vid. REBOLLO PUIG, M. y IZQUIERDO CARRASCO, M., «Protección de los legítimos intereses económicos de los consumidores u usuarios», en La defensa de los consumidores y usuarios (comentario sistemático del Texto Refundido aprobado por Real Decreto Legislativo 1/2007), 2011, pp. 313-342. 
o sean fácilmente determinables». Este es el concepto de interés colectivo, vinculado con la determinación de los sujetos afectados, diferente del interés difuso, que existe cuando los afectados no están determinados. Esta distinción se tiene presente en la legitimación que regula el artículo 11 LEC, pues los grupos de afectados están legitimados para defender los primeros mientras que los intereses difusos sólo pueden defenderse por las asociaciones de consumidores y usuarios que sean representativas. Dichas asociaciones son personas jurídicas y, por tanto, cuentan con la capacidad para ser parte en el proceso. Distinto es el supuesto de los grupos de afectados que carecen de personalidad jurídica, que es lo que ahora nos interesa.

Podrán ser parte en los procesos ante los Tribunales civiles, de acuerdo con el artículo 6.1. $7^{\circ}$ LEC, los grupos de consumidores y afectados por un hecho daños cuando los sujetos estén determinados o sean fácilmente determinables y, para demandar en juicio, será necesario que el grupo se constituya con la mayoría de los afectados. Para concretar quienes son los afectados, la LEC regula una diligencia preliminar por petición de quien pretenda iniciar un proceso para la defensa de los intereses colectivos de consumidores y usuarios al objeto de concretar a los integrantes del grupo de afectados cuando, no estando determinados, sean fácilmente determinables, que permite al Tribunal adoptar «las medidas oportunas para la averiguación de los integrantes del grupo, de acuerdo a las circunstancias del caso y conforme a los datos suministrados por el solicitante, incluyendo el requerimiento al demandado para que colabore en dicha determinación» (art. 256. 1. $6^{\circ}$ LEG). Determinados los consumidores y usuarios afectados, la comparecía en juicio del grupo corresponde a «las personas que, de hecho o en virtud de pactos de la entidad actúen en su nombre frente a terceros (art. 7. 7 LEG).

Resulta claro, por tanto, que el proceso civil diferencia el interés colectivo y el interés difuso por el grado de determinación de los titulares de tales intereses, no porque la relación jurídico material con el objeto del proceso sea diferente. Pero, en el proceso contencioso-administrativo, el que los consumidores y usuarios afectados por un hecho dañoso sean o no identificables no altera la legitimación de todos ellos a título individual, como titulares de un derecho subjetivo o interés legítimo del artículo 19. 1. a) $\mathrm{LJCA}^{59}$. Si son varias las personas afectadas, podrán constituirse en grupo de afectados y, en tal caso, la cuestión es el reconocimiento de la capacidad para ser

59 Por eso resulta criticable que la letra i) del artículo 19. 1, incorporada por la Ley Orgánica 3/2007, de 22 de marzo, se refiera a los intereses difusos en la legitimación en defensa de la igualdad de trato entre mujeres y hombres. De esta legitimación se ha ocupado especialmente DE LA TORRE MARTÍNEZ, L., «La legitimación activa del "interés difuso": ¿una nueva categoría para proteger la igualdad?», en RGDA núm. 40, 2015, e «Intereses colectivos y/o difusos del artículo 19.1 letra i) LJCA: ¿una ampliación de legitimación activa para la defensa del derecho de igualdad de trato entre mujeres y hombres?», en Intereses colectivos y legitimación activa, 2014, pp. 644 ss. 
parte en el proceso contencioso-administrativo de ese grupo, que es diferente de la legitimación en defensa de intereses colectivos que requiere habilitación legal ${ }^{60}$.

\section{b) Los grupos de afectados en el proceso contencioso-administrativo y el reconocimiento de su capacidad}

La afectación, como se ha señalado, no hace referencia a una relación con el objeto del proceso diferente del interés legítimo, concepto hoy día interpretado ampliamente por la jurisprudencia constitucional y ordinaria: la titularidad potencial de una ventaja o de una utilidad jurídica, no necesariamente de contenido patrimonial, por parte de quien ejercita la pretensión, que se materializaría de prosperar ésta relación material entre el sujeto y la pretensión (acto o disposición impugnados) de modo que su anulación produzca automáticamente un beneficio o perjuicio actual o futuro pero cierto. En consecuencia, un grupo de afectados es un conjunto de sujetos que ostenta una situación jurídico activa individual pero común a todos ellos frente a la Administración ${ }^{61}$. Sin duda, cualquier «afectado» podrá recurrir a título individual, aunque también pueden hacerlo conjuntamente. A tal finalidad podrán ser un grupo de afectados o crear una persona jurídica para la defensa de esos derechos e intereses comunes ${ }^{62}$. Para constituir una asociación es suficiente el acuerdo de tres o más personas que se comprometen a poner en común conocimientos, medios y actividades para conseguir unas finalidades lícitas y comunes, como, sin duda, es la defensa de los derechos e intereses legítimos de los asociados frente a la Administración. La asociación adquiere la personalidad jurídica y plena capacidad de obrar con el acta fundacional, que incluirá la aprobación de los Estatutos, no siendo exigible una inscripción, que carece de efectos constitutivos. Esta asociación, como cualquier persona jurídica, cuenta con capacidad para ser parte luego puede accionar ante la jurisdicción contencioso-administrativa en defensa de los asociados en los términos

60 Estas cuestiones se tratan con detenimiento en CARBONELL PORRAS, E., «Aproximación a los conceptos de interés colectivo y difuso en Derecho Administrativo español», en REDA núm. 159, 2013, p. 107 ss; también publicado en Por el derecho y la libertad. Libro Homenaje al Profesor Fuan Alfonso Santamaría Pastor, 2014, pp. 827 ss, así como en «Los intereses colectivos...», cit. p. 61 ss.

61 Para GONZÁLEZ PÉREZ, J. (2011: 290), se trata de un interés plural, que es el «interés individual de unos sujetos que se encuentran en la misma situación». En esta línea, GONZÁLEZ CANO, M I., La protección de los intereses legítimos en el proceso administrativo, 1997, p. 93, señala que existen «una pluralidad de intereses legítimos individuales de contenido cualitativo idéntico, caso en el que evidentemente cada uno de estos intereses es tutelable por cada uno de estos sujetos individuales afectados».

${ }^{62}$ En todo caso, esta asociación no defiende un interés legítimo colectivo, pues carece de la habilitación legal que exigen los artículos 7.3 LOPJ y 19. 1. b) LJCA, no siendo suficiente argumentar que el objeto del proceso está relacionado con su objeto social lo que supondría reconocer una «acción pública asociativa». La legitimación deriva del interés legítimo individual de los asociados que han optado por defenderlo conjuntamente. Vid. CARBONELL PORRAS, E. (2014: 68 ss.). 
ya vistos ${ }^{63}$. La ausencia o falta de acreditación de alguno de estos mínimos requisitos para la personificación de la asociación, identificaría a un grupo de afectados, que sería la organización no personificada creada por las personas titulares de la situación jurídico activa legitimante. Este grupo será parte en el proceso contencioso administrativo compareciendo en juicio mediante las personas que, de hecho o en virtud de pacto actúen en su nombre frente a terceros (art. 7. 7. LEG) ${ }^{64}$. Por lo anterior, en el proceso contencioso-administrativo no es preciso que los afectados estén determinados o sean fácilmente determinables ni que la demanda la formulen la mayoría como exige el proceso civil, pues cualquiera de ellos está legitimado para recurrir. Por eso, aunque capacidad y legitimación hacen referencia a dos requisitos procesales diferenciados, lo cierto es que cuando se trata de grupos de afectados ambas cuestiones están vinculadas: el acceso a la jurisdicción del grupo de afectados debe posibilitarse con interpretaciones flexibles sobre su capacidad precisamente porque está en juego la tutela judicial efectividad de derechos e intereses legítimos. En apoyo de esta conclusión es suficiente poner en relación los artículos 18 y 19. 1. b) LJCA: se reconoce la legitimación en el proceso contencioso-administrativo de los grupos de afectados, como estructuras organizativas al margen de la personificación.

\section{c) La capacidad de los grupos políticos parlamentarios}

Merece la pena prestar atención a la jurisprudencia del Tribunal Supremo en relación con la capacidad en el proceso contencioso-administrativo de los grupos políticos en los que se organizan los parlamentos estatal y autonómicos pues, como seguidamente se comprobará, se acepta su capacidad porque se les considera titulares de un interés legítimo subjetivo, en línea con lo aquí defendido respecto de los grupos de afectados.

63 La STS de 6 de julio de 2010 (recurso de casación núm. 4039/2006) señala que «la adhesión de unos propietarios a una Asociación no tiene otro objeto que el de agruparse en una persona jurídica para facilitar la defensa y gestión de sus intereses....Lo contrario sería privar de eficacia al derecho de asociación por imponer a cada uno de los asociados una actividad para la que se constituyó la persona jurídica a la que pertenecen, derecho que no puede quedar empañado o desconocido por el hecho de que algunos asociados reaccionasen, a título personal y particular, frente a la misma disposición y actos administrativos». En términos parecidos, la STS de 1 de febrero de 2003. También en la jurisdicción civil, la STS 623/2014 de 18 de noviembre (sala de lo civil; en recurso de casación y recurso extraordinario por infracción procesal 1671/2012), con cita de otras, reconoce a las asociaciones legalmente constituidas la posibilidad de ejercer las correspondientes acciones en defensa de sus asociados, admitiendo la legitimación de los compradores que se agrupan para la defensa de sus intereses legítimos, tendencia se ha reforzado aún más en la nueva LEC a través de sus artículos 6 y 11.

${ }_{64}$ Sobre la aplicación de los requisitos previstos en la LEC para constituir un grupo de afectados al proceso contencioso-administrativo, puede verse BUSTILLO BOLADO, R. O. (2005: 87-88) y GALVO ROJAS, E. (2000: 73). 
Inicialmente la conocida STS de 5 de marzo de 2014 se pronunció con ocasión del recurso contencioso-administrativo 64/2013, interpuesto por el Grupo Parlamentario Unión Progreso y Democracia contra los Reales Decretos de nombramientos de los Consejeros del Consejo de Seguridad Nuclear. La sentencia analiza con detalle la naturaleza jurídica de los grupos parlamentarios para negarles personalidad jurídica y, sobre esta base, comprobar la ausencia de una Ley que les reconozca capacidad procesal en el proceso contencioso-administrativo según prevé el artículo $18 \mathrm{LJCA}^{65}$. También se toma en consideración la jurisprudencia constitucional, que les reconoce capacidad para defender ante el Tribunal Constitucional las eventuales vulneraciones de los derechos fundamentales de sus miembros en relación con el ejercicio de su cargo representativo del artículo 23 de la Constitución, derechos que el Tribunal Supremo no considera afectados en el supuesto de hecho. Por último, se rechaza la aplicación a los grupos parlamentarios de la doctrina que ha reconocido la legitimación del grupo político municipal con apoyo en la específica regla del artículo 63. 1. b) de la Ley reguladora de las Bases del Régimen Local, pues ninguna legitimación similar se reconoce a los parlamentarios ${ }^{66}$. Consecuencia de lo anterior, la sentencia niega que el grupo parlamentario tenga capacidad procesal para recurrir, y se confirma con posterioridad ${ }^{67}$. No obstante esta conclusión fue polémica, como reflejan los tres votos particulares que incluye ${ }^{68}$. Recientemente el Tribunal Supremo

65 No obstante, la sentencia rechaza la excepción procesal de falta representación pues consta la certificación expedida por la Portavoz del Grupo Parlamentario, en la que se hace constar que, en reunión del referido Grupo, se acordó por unanimidad la interposición del presente recurso contencioso-administrativo y la escritura de poder para pleitos, otorgada por la Portavoz en representación del grupo.

66 La STS 7 de febrero de 2007 (recurso de casación 2946/2003) admite el recurso interpuesto por un grupo municipal pues todos sus integrantes habían votado en contra y expresado su voluntad de impugnar ante los tribunales, realizando una interpretación integradora de los artículos 18 y 19 LJCA. También la STS de 30 de junio de 2008 (recurso de casación 399/2004).

67 Esta sentencia se confirma en los Autos del Tribunal Supremo de 2 y 28 de abril de 2014, dictados en los recursos contencioso-administrativos 510/2013 y 172/2014 interpuestos por Grupo Parlamentario Unión Progreso y Democracia y su portavoz contra los Reales Decretos de nombramiento de los vocales del Consejo General del Poder Judicial y del Presidente del Tribunal Supremo y del Consejo, y del Vicepresidente del Tribunal Supremo. La no admisión de los recursos se explica en su falta de capacidad, remitiéndose a la sentencia de 5 de marzo de 2014, y su falta de legitimación: «los Grupos parlamentarios no poseen una legitimación universal que determine que todo objeto de debate político o de decisión parlamentaria pueda ser objeto de revisión jurisdiccional en sede contencioso-administrativa». También se invoca en la STS de 17 de junio de 2014, aunque concluye que se trataba de un acto parlamentario (de la Asamblea de Madrid para nombrar los miembros de la Cámara de Cuentas), sin valor de ley, no sujeto al control de la jurisdicción contencioso-administrativa.

68 De los tres votos particulares es particularmente extenso y detallado en el tratamiento de la cuestión el formulado por la Magistrada $\mathrm{D}^{\mathrm{a}}$. M $\mathrm{M}^{\mathrm{a}}$ Isabel Perelló Doménech, al que se adhieren varios magistrados. En lo esencial afirma la personalidad parcial, de base asociativa del grupo parlamentario, vinculada con la capacidad de esos diputados y diputadas, personas físicas incuestionablemente dotadas de capacidad, que extienden sobre el grupo parlamentario que los aglutina, así como el interés legítimo en participar activamente en el procedimiento para controlar los méritos y requisitos de los candidatos, en coherencia con 
ha vuelto sobre esta cuestión en la sentencia 386/2017, de 6 de marzo, que resuelve el recurso de casación 4016/2014 interpuesto contra la sentencia del Tribunal Superior de Justicia, que anula parcialmente el Decreto del Consejo de Gobierno del Principado de Asturias, regulando la aplicación de la prórroga de los Presupuestos Generales, en estimación del recurso contencioso-administrativo del Grupo Parlamentario Foro Asturias ${ }^{69}$. Se rechaza la pretendida inadmisibilidad por «falta de capacidad procesal o legitimación ad procesum del Grupo Parlamentario recurrente, así como la falta de legitimación activa ad causam por falta de interés directo». El argumento fundamental del Tribunal Supremo es que la capacidad procesal está en función del interés legítimo que ampara al grupo político que no «persigue un mero interés al cumplimiento de la legalidad, sino un interés propio a participar no en la elaboración de los presupuestos, sino en su participación, como grupo parlamentario, a través de la Junta General, en la autorización de gastos, emisión de duda, así como para la formalización de créditos». El Tribunal Supremo rechaza la infracción del artículo 18 LJCA, confirmando la apreciación de la sentencia de instancia, negando, además, que exista contradicción con su doctrina anterior con apoyo en la diferente naturaleza de los actos impugnados y el grado de afectación a los derechos de los representantes políticos, y, consecuentemente, a la legitimación para recurrirlos. Además niega que entre en contradicción con su sentencia de 5 de marzo de 2014 sobre la base de la «diferencia sustancial existente entre los procesos confrontados, en razón de la distinta naturaleza de los actos impugnados en uno y otro recurso contencioso-administrativo (cabe recordar a estos efectos que si la aprobación de los presupuestos son el resultado de un ejercicio condicional del poder público que incide en las relaciones entre el poder legislativo y el poder ejecutivo, la prórroga presupuestaria no requeriría de ningún acto de ratificación o convalidación - por su carácter automático - emanado del Gobierno). Procede, asimismo, advertir la desigual afectación de las funciones de los grupos parlamentario y el ius in officium de los diputados en uno y otro caso. En aquel supuesto - a diferencia del contemplado en este recurso de casación-, se considera que estaba justificado negar la capacidad procesal a un grupo parlamentario del Congreso de los Diputados para impugnar un Acuerdo del Consejo de Ministros, relativo al nombramiento de Consejeros del Consejo de Seguridad Nuclear, porque los derechos de participación política de los componentes del Grupo Parlamentario no se vieran afectados negativamente». Por

la función fiscalizadora de la acción del gobierno. Sobre esta sentencia y sus votos particulares, puede verse PÉREZ GARCÍA, M. L., "Sobre la falta de capacidad procesal de los Grupos Parlamentarios en el Orden contencioso-administrativo. Comentario a la Sentencia del Tribunal Supremo, de 5 de marzo de 2014 (Sala de lo Contencioso-Administrativo, Pleno)", en Revista Parlamentaria de la Asamblea de Madrid, núm. 31, 2014, pp. 233 ss.

69 En los mismos términos, la STS 863/2017, de 17 de mayo (recurso de casación 4016/2014), respecto del partido político Foro de Ciudadanos. 
lo tanto, puede concluirse que, para el Tribunal Supremo, la capacidad procesal de los grupos parlamentarios deriva del interés legitimador que les lleva al proceso.

Lo relevante de esta jurisprudencia es que el reconocimiento de la capacidad en el proceso de quién carece de personalidad se acepta en función de la legitimación, de la existencia de una situación jurídico-activa que la confiere en el sentido antes defendido. El Tribunal Supremo ha tratado a los grupos parlamentarios como si fueran grupos de afectados y, por eso, analiza conjuntamente la capacidad procesal con la legitimación; aceptada ésta admite que tenga capacidad. 


\section{BIBLIOGRAFIA}

Alarcón Sotomayor, L.: «El procedimiento administrativo», en Derecho administrativo II. Régimen jurídico básico y control de la Administración, en M. Rebollo Puig y E. Carbonell Porras (coors.), Tecnos, $3^{\text {a }}$ ed. Madrid, 2018.

Alonso Mas, Ma $. \mathrm{J} .:$ «La inadmisión del recurso contencioso administrativo por la falta de aportación del acuerdo para el ejercicio de acciones: el caso de las sociedades con administrador único», en Revista General de Derecho Administrativo núm. 45, 2017.

Álvarez-Cienfuegos Suárez, J. Mª . y González Rivas, J.J.: Análisis teórico y jurisprudencial de la Ley de la Furisdicción Contencioso-administrativa, Aranzadi, Cizur Menor (Navarra), 1998.

Armenta Deu, T.: Lecciones de Derecho Procesal Civil, 10 a ed. Madrid, Marcial Pons, 2017.

Asencio Mellado, J. Mª La Ley de Enjuiciamiento Civil comentada y con jurisprudencia, (coor.), La Ley, 2013.

Banacloche Palao, J. y Cubillo López, I. J.: Aspectos fundamentales de Derecho procesal civil, La Ley, Las Rozas (Madrid), $3^{\text {a }}$ ed, 2016.

Boto Álvarez, A.: «Las partes en el proceso contencioso-administrativo», en Estudio de la Ley de la Furisdicción Contencioso-administrativa, en A. Ezquerra Huerva y J. Oliván del Cacho (dirs.), Tirant lo Blanch, Valencia, 2014.

Bustillo Bolado, R.O.: La aplicación de la Ley de Enjuiciamiento Civil en el Contencioso-Administrativo, Thomson-Aranzadi, Cizur Menor (Navarra), 2005.

Calvo Rojas, E.: «Capacidad y legitimación», en Influencia de la Ley de Enjuiciamiento civil en el orden contencioso-administrativo y en el orden social, Consejo General del Poder Judicial, Madrid, 2000.

Cano Campos, T.: «Representación y defensa de las partes», en Revista Española de Derecho Administrativo núm. 100, 1998, número especial Comentarios a la Ley de la jurisdicción contencioso administrativa de 1998, Civitas, Madrid, 1999.

Carbonell Porras, E.: «Los intereses colectivos en la jurisdicción contencioso-administrativa», en Intereses colectivos y legitimación activa, en E. Carbonell Porras (dir.) y R. Cabrera Mercado (coor.), Thomson Reuters, Aranzadi, Cizur Menor (Navarra), 2014.

- «Aproximación a los conceptos de interés colectivo y difuso en Derecho Administrativo español», en Revista Española de Derecho Administrativo 
núm. 159, 2013; también publicado en Por el derecho y la libertad. Libro Homenaje al Profesor Fuan Alfonso Santamaría Pastor, en J. E. Soriano García (dir.) y M. Estepa Montero, (coor.), Colección Estudios Doctrinales, Iustel, Madrid, 2014.

- Los órganos colegiados (organización, funcionamiento, procedimiento y régimen jurídico de sus actos), Centro de Estudios Políticos y Constitucionales-Boletín Oficial del Estado, Colección Cuadernos y Debates núm. 83, Madrid, 1999.

- «Artículo 63», en Comentarios a la Ley Reguladora de las Bases de Régimen Local, en M. Rebollo Puig (dir.) y M. Izquierdo Carrasco, (coor.), II, Valencia, Tirant lo Blanch, 2007.

- «Incidentes e invalidez de los actos procesales», en Revista Española de Derecho Administrativo núm. 100, 1998, número especial Comentarios a la Ley de la jurisdicción contencioso administrativa de 1998, Civitas, Madrid, 1999.

- «La sustitución de los recursos administrativos ordinarios (o la alteración de algún elemento de su régimen general): algunas aportaciones generales ante el inmovilismo del legislador», en Nuevas perspectivas en la tutela de los ciudadanos frente a las Administraciones Públicas en A. Huergo Lora (coord.), Iustel, Madrid, 2018.

Cierco Sierra, C.: La participación de los interesados en el procedimiento administrativo, Real Colegio de España, Bolonia, 2002

Cordón Moreno, F.: El proceso contencioso-administrativo, Aranzadi, Cizur Menor (Navarra), 1999.

Cortés Domínguez, V. y Moreno Catena, V.: Derecho Procesal Civil. Parte general, $9^{\mathrm{a}}$ ed. Tirant Lo Blanch, Valencia, 2017.

De la Oliva Santos, Díez-Picazo Giménez, I. Vegas Torres, J. y Banacloche Palao, J.: Comentarios a la Ley de Enjuiciamiento Civil, Madrid, Civitas, 1ª ed. 2001.

De la Torre Martínez, L.: «La legitimación activa del "interés difuso": ¿una nueva categoría para proteger la igualdad?», en Revista General de Derecho Administrativo núm. 40, 2015.

- «Intereses colectivos y/o difusos del artículo 19.1 letra I) LJCA: ¿una ampliación de legitimación activa para la defensa del derecho de igualdad de trato entre mujeres y hombres?», en Intereses colectivos y legitimación activa, en 
E. Carbonell Porras (dir.) y R. Cabrera Mercado (coor.), Thomson Reuters, Aranzadi, Cizur Menor (Navarra), 2014.

Embid Irujo, E.: «Las partes», en Comentarios a la Ley de la furisdicción Contencioso-administrativa, en J. Leguina Villa y M. Sánchez Morón (dirs.), Lex Nova, Valladolid, $2^{\mathrm{a}}$ ed, 2001.

Gimeno Sendra, V., Moreno Catena, V., Garberi Llobregat, L. y González Cuellar, N.: Comentarios a la nueva Ley reguladora de la Jurisdicción Contencioso-administrativa de 1998, Centro de Estudios Ramón Areces, Madrid, 1999.

Gallardo Castillo, M ${ }^{\mathrm{a}}$. J.: Los problemas de la aplicación supletoria de la LEC en el proceso contencioso-administrativo, Madrid: Iustel, 2006.

Gómez-Orbaneja, E.: Derecho procesal civil, I, Artes Gráficas y Ediciones, Madrid, 1976.

Gómez Díaz, A.B.: La legitimación en el proceso contencioso-administrativo, Iustel, Madrid, 2014.

González Cano, M ${ }^{\mathrm{a}}$ I., La protección de los intereses legítimos en el proceso administrativo, Tirant lo Blanch, Valencia, 1997.

González Pérez, J.: Comentarios a la Ley reguladora de la furisdicción Contencioso-administrativa (Ley 29/1998, de 13 de junio), Civitas, Madrid, 6 a ed., 2011.

González Rivas, J. J. y Aranguren Pérez, I.: Comentarios a la Ley reguladora de la Jurisdicción Contencioso-administrativa 29/1998, de 13 de junio, Thomson-Cívitas, Navarra, $1^{a}$ ed., 2006.

López Benítez, M.: «La jurisdicción contencioso-administrativa», en Derecho administrativo II. Régimen jurídico básico y control de la Administración, en M. Rebollo Puig y E. Carbonell Porras (coors.), Tecnos, $3^{\mathrm{a}}$ ed., Madrid, 2018.

López Sánchez, J.: «La legitimación para el ejercicio de las acciones de cesación en defensa de los intereses colectivos de los consumidores y usuarios», en Intereses colectivos y legitimación activa, en E. Carbonell Porras (dir.) y R. Cabrera Mercado (coor.), Thomson Reuters Aranzadi, Cizur Menor (Navarra), 2014.

Martínez Gutiérrez, Á.: La representación orgánica y voluntaria en las sociedades de capital: (delimitación y concurrencia), Bolonia, Publicaciones del Real Colegio de España, 2005.

Menéndez García, P.: «Comentario al artículo 18», en Revista Española de Derecho Administrativo núm. 100, 1998, número especial Comentarios a la Ley de la jurisdicción contencioso administrativa de 1998, Civitas, Madrid, 1999. 
- «Capacidad procesal y legitimación ante la jurisdicción contenciosoadministrativa», en Por el Derecho y la Libertad. Libro Homenaje al Profesor Fuan Santamaría Pastor, en J. E. Soriano García (dir.) y M. Estepa Montero (coor.), I, Madrid, Iustel, 2014.

Montero Aroca, J. De la legitimación en el proceso civil, Bosch, Barcelona, 2007.

- La legitimación en el proceso civil (intento de aclarar un concepto que resulta más confuso cuando más se escribe sobre él), Civitas, Madrid, 1994.

Ortells Ramos, M.: Derecho Procesal Civil, $10^{\circ}$ ed, Aranzadi Thomson Reuters, Cizur Menor (Navarra), 2010.

Pera Verdaguer, F.: Comentarios a la Ley de lo Contencioso-administrativo, $7^{\circ}$ ed., Bosch, Barcelona, 2004.

Pérez García, M. L.: «Sobre la falta de capacidad procesal de los Grupos Parlamentarios en el orden contencioso-administrativo. Comentario a la Sentencia del Tribunal Supremo, de 5 de marzo de 2014 (Sala de lo Contencioso-Administrativo, Pleno)», en Revista Parlamentaria de la Asamblea de Madrid, núm. 31, diciembre, 2014.

Rebollo Puig, M.: «Responsabilidad sancionadora de personas jurídicas, entes sin personalidad y administradores», en Los retos del Estado y la Administración en el Siglo XXI. Libro-homenaje al Profesor Tomás de la Quadra-Salcedo Fernández del Castillo, en L. Parejo Alfonso y J. Vida Fernández, (coors.), Tirant Lo Blanch, Valencia, 2017; y en Revista Ius et Veritas, núm. 53, Diciembre, 2016.

Rebollo Puig, M., Gosálvez Pequeño, H., y Rodríguez Portugués, M. A.: «Artículo 21», en Comentarios a la Ley Reguladora de las Bases de Régimen Local, en M. Rebollo Puig (dir.) y M. Izquierdo Carrasco, (coor.), I, Valencia, Tirant lo Blanch, 2007.

Rebollo Puig, M. e Izquierdo Carrasco, M.: «Protección de los legítimos intereses económicos de los consumidores u usuarios» en la obra colectiva por ellos dirigida, La defensa de los consumidores y usuarios (comentario sistemático del Texto Refundido aprobado por Real Decreto Legislativo 1/2007, Iustel, Madrid, 2011.

Ruiz Risueño, F.: El proceso contencioso-administrativo, Madrid, Colex, 1998.

Santamaría Pastor, J. A.: La ley reguladora de la jurisdicción contencioso-administrativa. Comentario, Iustel-Gómez-Acebo\&Pombo, Madrid, 1, ${ }^{a}$ ed., 2010.

Tolivar Alas, L.: «Aspectos jurídico-administrativos de la protección de menores», en Revista de Administración Pública núm. 124, 1991. 